\title{
1968 年度秋季大会記事
}

本号は 10 月 5 日 (土) 29 日 (水)に亘って鳥取市 で開催された秋季大会の特集号として編集したもの で, 発表者の報告も論説並みの活字で組まれている.

10月 5 日, 県庁講堂における籠瀬良明・小堀篇 両君の公開講演を皮切りに山陰地方では始めての秋 季大会が鳥取市を中心にもたれた。

10月 6 日は, 午前中最近新らしく発足した都市地 理研究委員会・農業地理研究委員会・計量地理研究 委員会が，市内の白鬼荘・いなば荘で，それぞれ希 望メンバーによって開催され多大の成果を修めた.

午後は数台のバスに分乗し鳥取砂丘のエクスカー ションが行われた.

10月 7 日は湖山池が眼下に一望できる広々とした 新装の鳥取大学で, 谷岡武雄・河野通博両君の世話人 のもとで「海岸砂丘一その自然と開発」,「後進地域
の地域開発」の 2 つのシンポジウムが催された. 両 会場とも, 山陰地方にふさわしい問題点の指摘と提 案がなされ，多数の参会者の活発な討議が行われ， 盛会裏に意義ある集会を終えた。その後，会場を市 内に移し, 郷土色豊かな懇親会が開かれ，山陰の一 夜を大いに飲み，語り，会員相互の親睦と友好の情 を深めた。

翌 10 月 8 日・9 日は「鳥取県沿岸と大山」,「鳥取 県と中海・宾道湖周辺」,「鳥取県と中国山地」の $\mathrm{B}$.

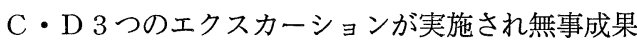
を执さめ終了した. 今回は日本地理学会始まって以 来, 最初の山陰地方における大会であったが，現地 では会員が少ないという困難な条件を克服され，岩 永 実教授を中心とする方々の準備の周到さと誠意 とには大きな感銘を受けた。

\section{海岸砂丘—その自然と開発}

\section{シンポジウムを終えて}

\section{谷岡武雄（世話人）}

まことにコンパクトなシンポジウムであった. 長 年にわたる研究に裏付けられた 8 つ問題提起, 通 常の大会報告にもまさる内容をもった 10 のコメン トがわずか 1 日の間になされたため，討論時間がい ささか不足した感じが残っている. 大会運営の都合 もあって1日でじゅうぶんとみなされ，最初はさほ ど多くの研究人口をもたないとまで思われていた砂 丘が，その実は研究の歴史が古いためにわずかな時 間では論じつくせないほど多くの問題をかかえてい ることを，証明する結果ともなった。

鳥取にふさわしいテーマとして砂丘を取りあげ， 自然地理・人文地理両分野はもちろん, 農学・地質 学など隣接科学からの参加をも得て, 自己のいわば 守備範囲を越え，相互に交錯して討論し合うことを 呼びかけた：これに応じて多数の方々が参会され， 前日午後に行なわれた砂丘エクスカーションの印象 が強烈ななかで熱心な討議が進められたことは，世
話人として感謝に堪えないところである. 交錯した 討論という点では必ずしも満足できなかったが，従 来しばしば見られたように, 自然と人文とで聴衆が ほとんど入れ代わってしまう現象は，今回はあらわ れなかった．この点で世話人の意図がある程度達成 されたように考えてはいけないだろろか，今後とも この種のシンポジウムがあってょいように思う．以 下感じたことを若干述べてみたい.

1）古砂丘と新砂丘との異同・関連については, 境界領域をなすためか地質学・地形学とも遠慮し合 ったように感じた.

2）三位氏が多雨期における砂丘の形成に触れ， 扇状地・崖錐・砂丘の同時期形成に着目し, 吉川座 長も平野地形発達の全体の過程のなかで砂丘発達史 を見るべきことを強調した.この点につき, 地形学 の立場からもっと積極的な意見が聞きたかった.

3）新砂丘の区分につき, 遠藤氏の地形学的立場 
と小野氏の考古地理学的立場との間に明らかなくい 違いがあった。この点の討論を竟つめるべきではな かったか. クロスナ，火山灰についても同様である.

4）小野氏は後水期海進のマキシマムが地域によ り異なること, 砂丘の形成期に地域的差違が見られ ることを主張し，コメンテーターとして多田氏も世 界諸地域にわたる事例から，同に゙時代に同じ砂丘が 出来るとは限らないと説明した，どこまでが一般原 則で, どこからは地域性にたよってよいか.この点 は地理学の方法論全体にかかわる問題であらう.

5）砂丘の形成営力に関する研究成果を地形発達 史や先史・歴史地理学にどのように生かすか. 三野 氏が質問されたごとく土壤学の成果の生かし方とと もに，論じられるべきではなかったか。

6）灌溉と水については，かなり技術論的に深め られた問題提起とコメントがなされた，農業地理・ 人文地理の側でどのようにこれらのデータを利用し うるか. これも今後の問題としてよかろう.

7）地理学では, 土地利用の問題を空間的分布の 面で考えていく．この点で農学における概念とはか なり異なるように感じた。
8) どちらかといえば，農学の側が地理学の成果 をじゅうぶんに吸収していないような感じを受ける。 水や地形，とくに植生のコメントを聞いて，この感 を深くした．純自然科学的狭量さといったものがあ るのだろうか。

9）砂丘利用の経済的な問題点，地域開発の問題 点に関して, 自然地理や農学の側からの意見がじゅ うぶん聞かせてもらえなかったのは残念である。保 存と開発との調和，工業的開発と農業的開発との関 連，過疎の中での砂丘開発のあり方，観光か住宅地 加等々問題は非常に多い.

発表と討論を通じて, 地形学・地質学・考古地理 学・農業地理学・農学などが意外に近いところを歩 いていることがわかった，それらのアプローチは異 なってもテーマが似ている場合も多い，鳥取大会を 一つの区切りとして，今後ますます研究が深められ るであろう.さほど遠くない将来, 第 2 回目の砂丘 シンポジウムが行なわれるかもしれない。またそう したいものである.おおりに地元の鳥取大学をはじ め参加者各位の御協力に深く感謝したい.

\section{1）日本の海岸地形と砂丘}

地質学の立場からみた海岸砂丘

\section{三 位 秀 夫*}

日本各地の第四紀研究グループによって, 海岸第 四系の層序と構造の概要が急速に解明されつつある. その結果, 海岸平野の前面に発達する “砂丘地” は 風成砂のみからなる単純な砂丘ではなく, 海成層・ 火山灰層・古土壌・泥炭層・段丘堆積物・基盤岩な どの複雑な組合せからなることが各地で確認されて いる. そして，各種の堆積物と風成砂との組合せに はあるていどの規則性があり，砂丘を形成した時代 がみとめられると同時に砂丘形成の休止期があるこ とが指摘されるに至った。

筆者は，第四紀研究グループとくに新潟古砂丘グ ループと山陰第四紀グループの成果を中心にして, 海岸砂丘の地質学的諸問題を整理して, 御批判と御 教示を仰ぐ資料に供したい．

\section{I 砂丘の形成時代}

風成砂と段丘堆積物との関係，砂丘中にはさまれ る火山灰・古土袞・人類遺跡・木片や貝壳片の ${ }^{14} \mathrm{C}$ 年代測定などを手がかりにして, 海岸砂丘地の層序 が各地で解明されている. 対比について疑問が残さ れてはいるが，おもな地域の層序を第 1 表に示した。 砂丘砂をともなう第四系で, 現在までに知られて いる最古のものは, 鳥根県温泉津町ふきんの都野津 層と秋田県本荘市南部の由利原層である. 前者は, 最下部にアカシ象や植物化石を産し, 大阪層群最下 部（鮮新世末期）に対比される. 風成砂は都野津層 最上部に最大層厚 $50 \mathrm{~m}$ で発達し, 花粉化石の組成 から大阪層群下部（前期洪禎世）に対比可能である

* 島根大学文理学部地学教室 
第 1 表海岸砂丘地における第四系対比表（*印：砂丘砂）

\begin{tabular}{|c|c|c|c|c|c|c|c|c|c|c|}
\hline 侍 域 & $\begin{array}{l}\text { 玄海砂丘 } \\
\text { (郷原 } 5 \text {,64) } \\
{ }^{2} 64 \text { ) }\end{array}$ & $\begin{array}{l}\text { 山口·安周 } \\
\text { (河野ら, } \\
{ }^{\prime} 65 \text { ) }\end{array}$ & $\begin{array}{l}\text { 出雲砂丘 } \\
\text { (三位ら } \\
\left.{ }^{\prime} 68\right)\end{array}$ & $\mid \begin{array}{c}\text { 鳥取砂丘 } \\
\text { (富島岛 } \\
\left.{ }^{\prime} 65\right)\end{array}$ & $\begin{array}{l}\text { 潟町砂丘 } \\
\text { (高田グル } \\
\text {-プ } 65 \text { ) }\end{array}$ & $\begin{array}{l}\text { 荒浜砂丘 } \\
\left(\begin{array}{l}\text { 柏㱦グル } \\
\text { ープ }\end{array}\right.\end{array}$ & $\begin{array}{l}\text { 本荘砂丘 } \\
(\text { 上北グル } \\
\text {-プ }\end{array}$ & \begin{tabular}{|} 
津軽十三湖 \\
(小貫ら, \\
${ }^{\prime} 63$ )
\end{tabular} \mid & $\mid \begin{array}{cc}\text { 八 } & \text { 戸 } \\
\text { (大池 } & \text { '65) }\end{array}$ & $\begin{array}{l}\text { 地形面区分 } \\
\text { (中川 '67) }\end{array}$ \\
\hline \multirow{2}{*}{$\begin{array}{l}\text { 沖 } \\
\text { 積 } \\
\text { 世 }\end{array}$} & 新砂丘* & 沖積砂丘* & 新砂丘 $2 *$ & 新砂丘 $2 *$ & 新砂丘* & 新砂丘* & 新砂丘* & 㺟風山砂丘* & 新砂丘* & \multirow{2}{*}{$\begin{array}{c}\mathrm{I} \\
\text { （蚛積面） }\end{array}$} \\
\hline & . & & 新砂丘 1 * & 新砂丘 $1 *$ & & & & & & \\
\hline \multirow{5}{*}{$\begin{array}{l}\text { 後 } \\
\text { 期 } \\
\text { 洪 } \\
\text { 積 } \\
\text { 世 }\end{array}$} & \multirow{3}{*}{$\mid \begin{array}{c}\text { 島郷砂層* } \\
\text { 鳥栖口-ム }\end{array}$} & \multirow{3}{*}{ 横野砂層* } & & 上部火山厕 & & \multirow{3}{*}{ 雪成砂層* } & \multirow{3}{*}{$\begin{array}{c}\text { 低位段乒 } \\
\text { 堆積物 }\end{array}$} & 五所川原 & 八戸火山灰 & \multirow{3}{*}{\begin{tabular}{|c} 
II \\
(低位段丘)
\end{tabular}} \\
\hline & & & \begin{tabular}{|l} 
吉原 \\
火山乍 \\
\end{tabular} & & & & & 高根硫層 & 三本 & \\
\hline & & & & 中部火山灰 & & & & & & \\
\hline & \multirow{2}{*}{ 若松層* } & \multirow{2}{*}{ 安岡層* } & 差海層* & 湯山砂層* & 潟町砂層* & 番神砂層* & \multirow{2}{*}{$\begin{array}{l}\text { 中位段乒 } \\
\text { 堆積物 }\end{array}$} & \multirow{2}{*}{ 山田野層* } & $\begin{array}{l}\text { 高館 } \\
\text { 火山灰* }\end{array}$ & \multirow{2}{*}{$\begin{array}{c}\text { III } \\
\text { (中位段丘) }\end{array}$} \\
\hline & & & 大池泥層 & 津ノ井泥層 & 平山層 & 安田層 & & & 高館層 & \\
\hline \multirow{2}{*}{$\begin{array}{c}\text { 中哄 } \\
\text { 期積 } \\
\text { 世 } \\
\end{array}$} & \multirow{2}{*}{ 岩屋碟層 } & & \multirow{2}{*}{ 山迴碟層 } & 下部火山灰 & & \multirow{2}{*}{ 青海川層 } & \multirow{2}{*}{$\begin{array}{c}\text { 高位段乒 } \\
\text { 堆積物 }\end{array}$} & & $\begin{array}{l}\text { 天狗柋 } \\
\text { 火山灰 }\end{array}$ & \multirow{2}{*}{$\begin{array}{c}\text { IV } \\
\text { (高位段丘) }\end{array}$} \\
\hline & & & & 御来歷磁層 & & & & & & \\
\hline $\begin{array}{c}\text { 睊暴 } \\
\text { 世積 }\end{array}$ & & & \begin{tabular}{|c|} 
大江高山 \\
石英安山岩 \\
都野津層*
\end{tabular} & & & & 由利原層冰 & & 天狗代砂層 & $\begin{array}{c}\mathrm{V} \\
\text { (九戸段丘) }\end{array}$ \\
\hline
\end{tabular}

由利原層は，万願寺動物化石群を産する鮮新世西目 層を軽微な不整合で打抢う砂磁泥層からなり，この 上部に偽尿の発達した層厚 $10 \mathrm{~m}$ 前後の風成砂が整 合にのる. これらの砂丘砂は, 火砕流堆積物や古土 壌によって細分が可能であり，両層の風成砂は少く とも上下に 2 分することができる.これらの風成砂 の堆積期は，一括して九户段丘形成期》に対比され る。

高位段丘堆積物には風成砂が確認されていない. 中位段丘堆積物（下末吉層相当層）には，上部に風 成砂をともならのが普通である，柏崎の荒浜砂丘 ${ }^{2}$. 鳥取砂丘 ${ }^{32}$ ・出雲砂丘などでは, この風成砂が大規 模な砂丘を構成している，古砂丘 I と呼ばれてい $3^{4)}$.

低位段丘堆積物中ないしこれと同層準の砂丘とし ては，玄海・安岡・荒浜砂丘などで確認されている にすぎない，しかし，淡黄色の細粒砂からなる特徵 的な砂層であり，古砂丘川と呼ばれている4). これ らの風成砂は, 古土堙のはさみによってさらに細分 が可能ではあるが，ここでは低位段丘堆積物と密接 な関係にあるという点で一括する. ある地域で細分
される砂層を安易に他地域の砂層に対比するのは, 現段階では困難であるためである.

沖積層と関連の深い砂丘には，泥炭や人類遺跡な どによって詳しい細分が行なわれているが，本文で はふれない.

上記のように，日本沿岸における第四紀海岸砂丘 の層序的位置は，九户・中位・低位段丘堆積物戈よ び沖積層の 4 層準に大別することができる，それぞ れの砂丘はさらに細分されるので，第四紀をつうじ て 4 回だけ砂丘形成期があったというのではなく， 大別した 4 層準に関しては砂丘形成に同時性をみと められるという意味である.

\section{II 砂丘の内部構造}

砂丘砂は，局地的には基盤岩ないしより古い第四 系の上を不整合におおって発達するが，しかし多く は海成層ないし潟湖性堆積物の上位か海側部に整合 的に発達する.

九戸段丘形成期に対比される都野津層では，上部 に 5 枚の火砕流堆積物がはさまれ，鍵層として有効 である ${ }^{5)}$. 下位から 2 番目と 3 番目との火砕流堆積

1) Nakagawa, H. (1967) : Quaternary sea levels of the Japanese Islands. Jour. Geosci., Osaka City Univ., Vol. 10, Art 1-5, 37 42.

2）柏崎平野団研グループ（1965）：柏崎平野の第四系。新潟大教育高田分校紀要，10，145〜185.

3）豊島吉則・赤木三郎（1965）：鳥取砂丘の形成について。鳥取大学芸研報, 16(1)，1１4.

4）新潟古砂丘グループ (1967)：日本海側の古砂丘について. 第四紀研究, 6(1), 19 28.

5）都野津団研グループ（1968）：大田市大家周辺の都野津層群。大阪層群総研連絡紙，3，13〜16. 
物の間に砂丘砂の主要部があり，これと同一層準な いしわずか下位に海成泥層をはさむ潟湖状堆積物が 分布する. 厚い砂丘砂は基盤岩の突出部にかぎって 発達し，この層準より下位の都野津層を欠除するの が特徵である.すなわち, 都野津層形成時の低地は 潟湖として埋積され, 基盤の突出部に砂丘を形成し ている.

都野津層のばあいは，その後の削剝と開析作用と によって, 地形的な砂州と潟湖との配置は保存され ていない. しかし，上記のように地質的には砂州と 潟湖との組合せからなる点は注目されよう。これに 反して，中位段丘堆積物上を整合におおう砂丘砂 (古砂丘 I ), 低位段丘堆積物と同層準の風成（古砂 丘 II)，および沖積世砂丘は，いずれも砂州と潟湖 との配置として海岸地形を構成している.

中位段丘堆積物が砂州と砂丘を形成しているばあ いには, 形成当時潟湖であったと予想される位置に 沖積層が発達するため, 砂州と潟湖との復元がむず かしい，しかし，鳥取砂丘では火山灰層序からみて 砂丘砂と同層準であろうと考えざるをえない泥層が 内陸部に分布する ${ }^{3)}$ など, 中位段丘堆積物の形成期 にすでに現在みられる砂州海岸の原形が完成してい たと推定される例が多い(6).

ここで強調されることは，ひとつづきの海岸地域 に掞いて, 形成時代を異にする砂州と砂丘とが共存 している点である. 日本の太平洋沿岸では資料不足 のため不明であるが，少くとも日本海沿岸では，後 期洪積世から沖積世に至る期間，ほぼ同じ位置に砂 州と砂丘および舄湖が形成されていたものと判断さ れる. 各時期の海水準はそれぞれ相違するにもかか わらず，形成位置が似ていることは注目されよう。 九戸段丘堆積物中の砂丘と潟湖の配置が現地形とは 無関係であることから, 現在みられる海岸砂州と砂 丘および潟湖の発達位置が決定された原形，すなわ ち半島と湾入との成立は, 九戸段丘形成後中位段丘 堆積以前と推定される.

\section{III 砂丘の堆積過程}

砂層には風成と水成との 2 大別のほか，風で運ば れて水中に堆積したものや 2 次的に崩落したものな
どがあり，砂層からこれら堆積機構の区別をつける ことは, 砂層の堆積過程を考察するために重要な課 題である. 偽層や層理の形式・粒度組成・砂粒の円 磨度や表面の傷跡・鉱物組成などの堆積学的検討が 必要である. 不充分ではあるが，現在までに知られ た大要をまとめると次のとおりである。

層理やラミナの発達は，風成・水成ともにみとめ られるが，その型式にわずかの差異がある. 水成砂 では，一般に水平な層理やラミナが発達し，下位が 粗粒で上位へ漸次細粒になる grading の現象がみら れる.この grading は，厚さ $30 \mathrm{~cm}$ ていどのものか ら $1 \mathrm{~cm}$ 以下のごく薄いものまであり，肉眼的には 鑑別できないわずかな grading のことも多い，風成 砂では，大規模な偽層や不規則に乱れた 2 次的ラミ ナ状模様が発達し， grading はみとめられない.す なわち均質な砂からなるのが特徴である.さらにま た, 2 次的な崩落砂では, 数 $\mathrm{cm}$ の単位で逆の grading（下位が細粒上位が漸次粗粒）をなすことが多い. 砂層の粒度組成から，平均粒径・淘汰度・歪度の 3 要素について検討すると, 一般的傾向としては風 成砂の方が淘汰が良く，3要素とも上下変化が非常 に少ないと云える，砂の円磨度は，風成砂が高い值

（丸味）を示すことが多いしかし，これらの統計 処理から判断すると, 単純に堆積環境を推定するの は危険であり，砂層には地域性と時代性（歴史性） とのあることをみとめざるをえない，地域性は砂の 供給源の差異にもとずくものであろうし，歴史性は 既存の砂層が浸蝕されて次の時代に再堆積するため に生じるものと考えられる。

砂丘砂が海成ないし潟湖性堆積物の海側部か上位 に発達することに注目すれば，海退にともなって砂 浜が拡大し，この裸地が砂の供給源となって砂丘が 形成されるものと推定される. 少くとも九戸 - 中位 段丘堆積物にともなう砂丘は，海面低下によって砂 丘が形成されたと説明すると好都合である.

奄美群島において沖積砂丘がもっとも大規模に発 達するのは喜界島である，島ごとの沖積世離水サン ゴ礁の標高を比較すると，喜界島が相対的にもっと も隆起の傾向にある72. すなわち隆起にともなう相 対的海退が，大量の砂丘砂を供給した原因であろう.

6）三位秀夫（1966）：沖積世における海岸砂州の発達過程．第四紀研究，5，139１48.

7）三位秀夫・木越邦彦（1966）：奄美群島喜界島の旧汀線堆積物と海岸砂丘との ${ }^{14} \mathrm{C}$ 年代. 地球科学, 8,43 $\sim 45$. 
一方, 沖積層と低位段丘堆積物にはさまれる風成 砂の一部は，海退期とはかぎらずむしろ海進中ない し低位海面期に対応して形成されている. 既存の砂 層が風食によって再堆積したり，大陸におけるレス 状砂形成の一環として形成されたものと推定される. とくに低位段丘堆積物にふくまれる風成砂（古砂丘 II）は, 帯黄色の細粒砂によって特徴つけりれ, 粘 土鉱物・化学組成ともにレス状砂が多量に混入して いると考えるのに好都合である4)8).

玄海砂丘のばあい珪酸係数 $\left(\mathrm{SiO}_{2} / \mathrm{Al}_{2} \mathrm{O}_{3}\right)$ が 3 前 後であり,この值は中央アジアの乾燥地域における
レスに類似する. 砂丘形成に乾燥気候が必要とはか ぎらないであろうが，しかし砂浜の離水をともなっ ていない砂丘では，乾燥気候を想定すると説明しや すい．低位段丘形成期（ヴュルム氷期）には，日本 各地で大規模な扇状地堆積物や崖錐堆積物が形成さ れており，この時期に風成砂の堆積もみとめられる わけである.たとえば雨期と乾期とのくり返しが明 瞭であり，乾湿交代による風化作用が著るしかった のかも知れない.この立証は，今後に残された課題 の一つである.

\title{
COASTAL DUNES IN JAPAN, THEIR GEOLOGICAL CONSIDERATION
}

\section{Hideo MII*}

Dune sands with four different phases of a Quaternary sequence are recognized along the Japanese coast as, those which occur in the early Pleistocene sediments, those which are conformably superposed on the marine sediments forming a middle terrace (Riss-Würm interglacial stage), those intercalating with the volcanic ash or fluviatile deposits during a last conspicuous lowering of sea level (Würm glacial stage), and those developed during the Holocene in age. These horizons of eolian sand can be subdivided into two or three, respectively, based on the intercalating ancient soil, peat, and pyroclastic deposits.

Of those some eolian sands are possibly supplied and deposited from the beaches extended wide during the fall in sea level. Others are probably due to a wind action under the condition of rather arid climate. From the viewpoint of stratigraphical relation and sedimentological analysis, it is interpreted that the eolian sands of the early Pleistocene and Riss-Würm interglacial stages may be related with the fall in sea level. The sands of the Würm stage may be supplied from the ancient sand bed covered with poor vegitation, probably under the arid condition. The chemical composition and clay minerals suggest that the later sands more or less contain loess-like particles.

\section{日本における沖積世の砂丘の形成について}

\author{
遠藤 邦 彦** \\ Iはじめ に \\ 日本の砂丘地帯には, 太平洋岸, 日本海岸を問わ \\ ず，全国的に黒色腐植質砂層が分布している.この
}

8）新堀友行ほか（1964）：北九州の玄海砂丘の意義. 資源研報，63，49 63.

Geographical Review of Japan 42-3. * Dept. of Geol., Shimane Univ.

** 東京大学大学院 
沖積世に形成された砂丘砂層中に埋没された腐植質 砂層については，川田 ${ }^{13}$ が内灘砂丘に関して報告し ているのをはじめ, 多くの記載がある. 豊島・赤 木22) は鳥取砂丘において，これをクロスナ層と呼ん だ.このクロスナ層は, 砂丘地帯に広く連続的に分 布することから，人為的なものではなく，沖積世に おいて，長期にわたり砂の移動が行なわれず，極め て安定していた時期に形成された土壤層であり, 従 って，砂丘の固定期を示すものである.

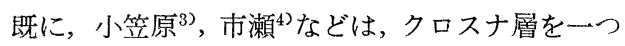
の手掛りとして, 日本の砂丘の形成を論じている. 筆者は, クロスナ層が全国的に分布すること, 更に, 砂丘地帯には遺跡・遺物が比較的よく保存されてい ることから,クロスナ層に含まれている遺物や, ク ロスナ層中の炭による C-14 年代測定などによって, クロスナ層の時代を決定し, 更に, これに基いて全 国的な対比を試みた. 特に, クロスナ層と遺跡・遺 物の関係については厳密を期し，筆者自身が露頭に 於て発見したもの, 及び, 発掘者に出土地点, 出土 層などを確認しえたものだけを資料として採用した。

\section{II クロスナ層と砂丘の形成期}

クロスナ層は多くの砂丘地帯で二層見られる。そ れぞれ，旧期クロスナ層 (Ho) 及び，新期クロス ナ層 $(\mathrm{Hy})$ と呼ぶ. 第 1 図に, これらが標式的に 発達する北海道礼文島船泊砂丘の模式的な断面を示 した.

旧期クロスナ層は, 沖積世の砂丘を, 旧砂丘, 新 砂丘に大きく二分するもので, 一般に, 黒色 暗褐 色を呈し, $30 \mathrm{~cm}$ 以上の層厚をもっている. 新期ク ロスナ層は, 暗褐色を呈し, 層厚は一般に $5 \sim 10 \mathrm{~cm}$ で，二層或いは数層に分れていることがある.

旧期クロスナ層に覆われる旧砂丘 (Do) は，かな り風化されて褐色を帯び, 固く締っている砂丘砂層 からなる. これに対して，新鮮でルーズな灰色砂丘

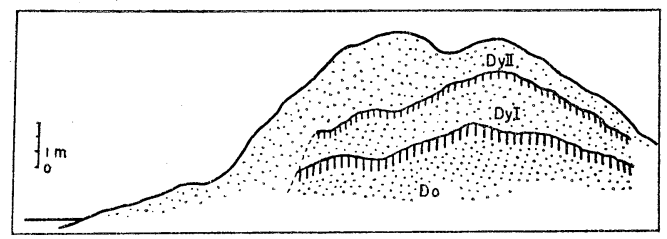

第 1 困礼文島の砂丘一模式断面図

砂層よりなる新砂丘は，間に挾まれる新期クロスナ 層によって，新砂丘 I (Dy I ), 新砂丘 I (Dy II) に 二分される.

このように，多くの砂丘地帯では，二期のクロス ナ層によって, 沖積世の砂丘の形成期は三期に分け られる。

クロスナ層や砂丘砂層或いはその基盤などに含ま れる考古学的遺物の時代や，C-14 年代によって, 二期のクロスナ層, 三期の砂丘の形成時代を決定し, 全国的な対比を行なった結果，これらの形成期は全 国的にかなり一致していることが明らかになった． 代表的な砂丘地带については，その結果を第 1 表に 示した. 以下, 各期砂丘, 各期クロスナ層について 説明する.

1) 旧砂丘 (Do)

多くの地域では, 沖積世の最大海進によって形成 された，砂洲や沖積段丘上に発達している.このよ うな場合, 旧砂丘の形成は, 海面高頂期及びその後 の海退期に行なわれたものと思われる5. 海面の高 頂期は，地域によってかなりの巾をもつと考えられ るが，一般にいわれる繩文前期中葉と仮定した場合， この時期に旧砂丘形成の下限を求めるのが妥当と思 われる。

神奈川県大磯砂丘は, 標高 $20 \mathrm{~m}$ の神積段丘上に 発達している.この段丘堆積物中の貝化石による $\mathrm{C}-14$ 年代は, $7840 \pm 100$ 年 B. P. (GaK-1598), 8760 \pm 100 年 B.P. (TK-29) である ${ }^{6)}$. また, 島根県出 雲砂丘の基底泥炭の C-14 年代は， $7840 \pm 130$ 年 $\mathrm{B}$.

1）川田三郎 (1947)：日本に於る埋積砂丘. 資源研彙報, No. 10, 55 58.

2）豊島吉則・赤木三郎（1965）：鳥取砂丘の形成について. 鳥取大学芸学部研究報告, 16-1

3）小笠原義勝 (1951）：日本の風蝕地形に関する一考察. 資源研彙報, No. 19-21, 110-118.

4）市瀬由自（1962）：平野の形成と海岸砂丘. 資源研彙報, No. 56-57, 51-61.

5）新潟平野他の, 砂丘列をなしている砂丘地帯で, 最も内陸側に旧砂丘が発達していることは, この時期 に最も海面が高かったことを示す.

6）これらの年代は測定した貝の層準から海面高頂期を若干さかのぼる年代である. 関東地方での海面高頂

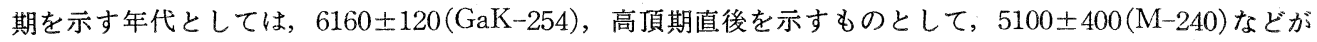
ある〔米倉他（1968）：相模湾北岸の沖積段丘．第四紀研究，7，49５5.〕 
P. (GaK-589) である7)

これらの年代は，旧砂斥形 成の下限を示すものであ る.

一部の地域では, 洪積段 丘や第三系丘陵を覆って旧 砂丘が発達する（前者は下 北半島など, 後者は房総半 島など). 下北半島では， 洪積段丘上に旧砂丘がのり あげており，この旧砂丘中 に繩文早期の土器が含まれ ている8). 従って, 旧砂丘 の形成開始期は，これらの 地域では少なくとも繩文早 期までさかのぼるものと思 われる。

秋田平野や下北半島で は, 旧期クロスナ層の最下 部が薄く何層にも分れ, 砂 丘砂との互層になっている 所がある。これは固定化へ の移行期を示すもので，この部分より繩文中期の土 器が発見されることから旧砂丘は繩文中期比缜ら固 定されはじめたものと思われる。

2）旧期クロスナ層 (Ho)

旧期クロスナ層の分布高度は, 内灘砂丘で海面下 にまで達するのをはじめ, 下北, 秋田等各地で海面 高度近くまで分布し，また同じ時期の泥炭層が海面 下に分布している地域も少くない.このことから， 旧期クロスナ層は海退期に形成されたものであり， その当時の海水準は現在よりも低かったと思われる. 藤井 ${ }^{9)}$ は, 最近の日本の海面変動について考察し, $3000 \sim 1500$ 年前には， $0 \sim-2 \mathrm{~m}$ に海面があったと考 えている.

旧期クロスナ層は, 繩文中期から弥生までの土器 を出土する. 繩文後期及び弥生の土器, 特に前者は 殆んどの地域で多数発見されており, 後期から弥生

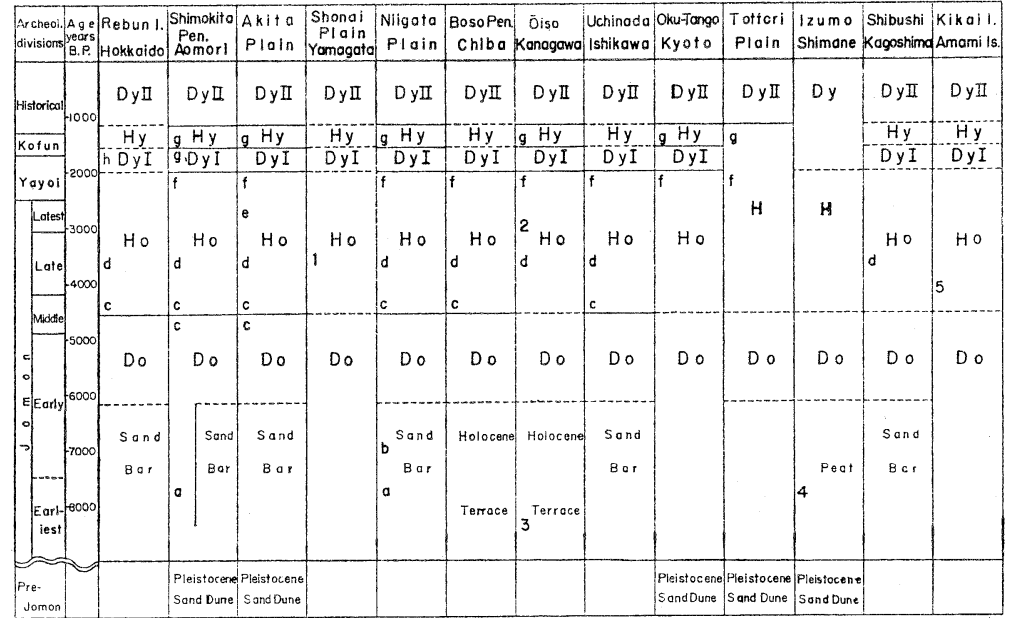

Do：旧砂丘, Dy I : 新砂丘 I, Dy II : 新砂丘 II, Ho : 旧期クロスナ層, Hy : 新期クロスナ層, $\mathrm{a}-\mathrm{h}$ ：出土する土器 [a. 繩文早期, b. 繩文前期, c. 繩文中 5. $4360 \pm 140(\mathrm{GaK}-451)$, 三位・木越 (1966)]

なおここの表を作成するにあたり，下北半島は大矢・市瀨(1958)，秋田平野は藤岡(1966)， 内灘は藤(1966), 舄取は鼌島・赤木(1965), 出雲は三位他(1967), 志布志は大矢・市瀬・和 皂(1959)，喜界島は三位・木越(1966)を参考にした。

にかけては，砂丘が最も安定していたものと思われ る.

大磯砂丘の旧期クロスナ層に含まれる炭の C-14 年代, $3000 \pm 180$ 年 B.P. $(T K-48)^{100}$ や, 庄内砂丘 の同様の C-14 年代, $3550 \pm 100$ 年 B.P. (GaK1235) ${ }^{11}$ は，ともに旧期クロスナ層形成期の平均值 を示すものと考えられ，土器の時代から推定された 年代とほぼ一致する.

3) 新砂丘 I (Dy I )

弥生末期から古墳時代にかけて形成された砂丘で, 特に東日本で大規模に発達し，洪積段丘や $100 \mathrm{~m}$ を 越える丘陵にのりあげているところもある. 列状を なす砂丘地帯では，現海岸線に沿って分布する新砂 丘Пの内陸側に位置し，当時の海面は，前の海面低 下期より若干上昇していたものと考えられる.

4）新期クロスナ層 ( $\mathrm{Hy})$

7）三位秀夫他 (1967)：出雲砂丘地における古砂丘の ${ }^{14} \mathrm{C}$ 年代. 地球科学, $21 ， 5 ， 45-46$.

8）大矢・市瀬（1958）：下北半島の海岸砂丘。資源研彙報，No. 46-47，5-12.

9）藤井昭二（1967）：沖積層とその絶対年代．第四紀研究，6，192 199.

10）神奈川県大磯町西小磯，沖積段丘上の砂丘中に見られる旧期クロスナ層に含まれる炭の細片を測定.

11）中馬・高橋 (1968)：山形県庄内砂丘の古砂丘の絶対年代. 地球科学，22，1，42. 
二層ないし数層に分れることがある.比較的短い 不安定な固定期である.下北，秋田他，いくつかの 地域で, 古墳時代から奈良時代にかけての土師器, 須恵器を出土する. 現在の段階では，充分な資料が あるとはいえないが，古墳時代から奈良時代にかけ て形成された可能性が強い，鳥取や出雲などでは， 明瞭な新期クロスナ層が発見されていないが，層厚 が薄く，腐植含有率も低いものであるだけに，分解 の速い西日本では保存されにくいことも考慮すべき であろう。しかし, 山陰でも, 島根県恵曇の小規模 な砂丘中に, 弥生時代及び奈良時代の二層の土器包 含層が見られる. また, クロスナ層が不明瞭であっ たり, 土器との関係が明らかでない地域でも, 砂丘 中に，この時期の遺跡が分布することが多い.

5) 新砂丘 II (Dy II)

平安時代前後以降，現在に至るまでに形成された 砂丘である. 各地で, 海岸線沿いに大規模に発達し ている．歴史資料から，最近 $600 \sim 700$ 年間に激し い砂の移動が行なわれたことがうかがえる. 現在は 固定作業によって殆んどが固定されているが，下北 半島や北海道の一部などでは, 現在な打移動してい る砂丘がある.

\section{III 砂丘の形成と固定の原因}

砂丘の形成には, 砂の供給と, 砂を移動させる営 力一気候条件一一二つの条件が不可欠である. 既に述べたように, 砂丘の形成や固定は, 沖積世に
於ける海面変動と対応している. 旧砂丘は高海水準 の時期に形成され，新砂丘は小海進が形成のきっか けになっている可能性が強い，一方，低海水準に対 応するクロスナ層の形成は，単に海退によって砂の 供給が断たれたということでは説明できない，とい うのは，新・旧砂丘形成期には，海岸線から遠くは なれた段丘上や丘陵にまで砂が移動しているからで ある. このように, 砂の供給に影響を与える海面変 動のほかに，気候変化をも考慮する必要がある.

阪口 ${ }^{12)}$ は，花粉分析及び分解度分析から，B.C. 1000年頃に，それまでの温暖で乾燥した気候は急変 し，気温の低下，湿潤化が起ったが，それは紀元前 後に終ったとしている．また，藤井 ${ }^{133}$ は，旧期ク口 スナ層の時期に対応する魚津の埋没林の樹種から, 当時は現在より寒冷であったとしている. 藤井・ 藤 ${ }^{14)}$ は花粉分析結果より, climatic optimum の後, $4000 \sim 3000$ 年前から 1500 年前までの間に寒冷な時 期があるとしている.

砂丘地に腐植が集積されるには，現在より寒冷で 湿潤な環境は好適であろう。このようなことから， 旧期クロスナ層の形成には，気候の寒冷化，湿潤化 が密接に関係していると考える.

以上の考察や，砂丘の形成・固定が全国的に一様 に起っていることから，砂の供給に影響する海面変 動と，砂の移動，腐植の集積を左右する気候変化と が，砂丘の形成と固定をくりかえさせてきた主要な 原因であると思われる.

\section{THE FORMATION AND FIXING OF HOLOCENE SAND DUNES IN JAPAN}

\section{Kunihiko ENDO*}

In this paper the writer discusses the formation and fixing of Holocene sand dunes in Japan.

The buried black humus sands, called Kurosuna beds, are widely distributed in the sand dune regions all over Japan. Humus sands are classified into two by the stages of formation, namely Older humus sand and Younger one. Older humus sand, more than $30 \mathrm{~cm}$ in thick-

12）阪口 豊（1961）：北日本の完新世の気候変化．地理評，34，259 268.

13）藤井昭二（1965）：黒部川扇状地の形成と富山湾周辺部の埋没林について. 地球科学, 78, 11 20.

14) Fujii, Fuji (1967) : Postglacial Sea Level in the Japanese Islands, Journal of Geoscience, Osaka City Univ. 10, 43 51.

Geographical Review of Japan 42-3 1969. * Tokyo Univ. Postgarduate Course. 
ness, is well packed and covers brown dune sand well weathered (Older sand dune). On the other hand, Younger humus sand, about $10 \mathrm{~cm}$ in thickness, is not well packed and covers grey dune sand less weathered (Younger sand dune).

The stages of the formation of sand dune are divided into three by two humus sands in many regions.

By archaeological relics included in humus sand or dune sand, the each stage of humus sands is decided in every region. According to the correlation of each stage, it necessarily follows that the formation of sand dune or humus sand occured simultaneously all over Japan.

Older humus sand was formed from Jomon Middle to Yayoi throughout the country, and Younger one was formed probably from Kofun to Nara. While Older sand dune, covered with Older humus sand, was formed before Jomon Middle. The sand dune developed on the sand bar formed after the stage of maximum transgression of Recent. Younger sand dune I was probably formed from Yayoi to Kofun and well developed in the eastern part of Japan. Younger sand dune II, has been formed since Kofun or Nara, develops on the largest scale. Some records of the movement of sand after Muromachi or Edo are found in various regions.

It is probable that the agency and condition that caused the formation and deformation of sand dune are closely related to the fluctuation of climate and the change of sea level during Holocene.

\section{考古地理学からみた海岸砂丘の形成 一西日本の場合——}

\section{小野 忠 箘*}

\section{Iまえがき}

このシンポジュームに㧊いて筆者に与えられた課

題は, 考古地理学の立場 ${ }^{1)}$ から海岸砂丘を人類の生 活舞としてとりあげ，砂丘が形成された時期を明ら かにするとともにそれらから引き出される諸問題を 指摘することである. そこでこの目的にそうために， 砂丘に遺した人類の遺跡や遺物を土地や地域に結び つけ，このような文化化石としての遺跡と遺物を決 め手として，地形や地層の鍵層との関連から海岸砂 丘の発達期と固定期をとらえて砂丘の編年を試み, 併せてそれらから帰納される幾つかの問題を指摘す

\section{ることにした.}

今回試みた砂丘編年の指標と条件は，1．地層に 結びついた文化期を示す遺跡と遺物を中心として, 2. それらの産出層準と段丘地形や気候土畩として の赤色土の有無と赤土化の程度との関係，3. 飛砂 の供給源になった砂堆の形成時期と，4. 火山灰層 や腐植土層などを拠りどころにした。

直接の対象とした厚みある空間は，日本の土地に はじめてヒトが出現し，大自然が住民の環境になっ

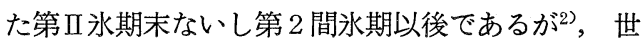
界的にはヒトの出現がほぼ第四紀に相当 ${ }^{3)}$ するので， ここでは洪積世から沖積世にわたる第四紀の海岸砂

* 山口大学

1) 藤岡謙二郎 (1962)：考古地理学とその課題. 近畿古文化論攻, 所収. 小野忠笪 (1966) : 考古地理学の意義. 考古学ジャーナル No. 3.

2）古代学協会編（1962）：大分県丹生遺跡第一次発掘調査概要. 小林達夫・阪口 豊 (1962)：大分県丹生台地出土の旧石器の時代について. 地理評， 35, 7. 小野忠潶 (1968)：山口県磯上遺跡の水晶集積址と旧石器. 考古学研究, 14 の.

3) Movius, H. L. (1948) : The Lower Palaealithic Cultures of Southern and Eastern Asia. Clark, G. (1962) : World Prehistory an Outline. 
丘を扱うことにしだまた用いた資料は，箨者自身 発掘して得た知兒や，踏査に上って直接観察したり 採集した資料を中心に，先学や学友の文献と教示に 拠った. 考古地理学の立場や方法加する海岸砂丘 の編年的研究は緒についた域を出ず，編年の鍵とな る考古試料の再吟味と, それらを地形や地層に結び つけて考古地理学の資料を作るという基礎的作業が 数多くのこっている. 現在の段階では絶対年代の決 め難い洪積世や沖積世初期の砂丘があるので, 今回 の編年は砂丘の新古の順序とごく概括的な文化期上 の位置づけを行なうことにした。

なお本稿は，1968 年 10 月のシンポジュームの際 の教示や批判を参考にし，その後の新知胃を加えて 再検討を行ない，当日配布したシンポジュ一ム討議 資料「考古地理学からみた海岸砂丘の形成時期と諸 問題一一西日本を中心として一」の一部を訂正し， 紙数の都合上圧縮したものである.

\section{II 海岸眇Exの形成時期}

洪積世の砂丘の形成期は 5 回みつかっており,こ れらの表層はいずれも赤土化作用をうけて「赤い砂 丘」をなし，記述の都合上それぞれ古砂丘 I・II・ $\mathrm{III}_{\mathrm{a}} \cdot \mathrm{III}_{\mathrm{b}} \cdot \mathrm{IV}$ とよんでおく．沖積世の砂丘は飛砂 層程度の広義の砂丘を含めると 5 回の形成期が指摘 できるので, 記述の便宜上仮りに新砂丘 I ・ II ・ III・ $\mathrm{IV}_{\mathrm{a}} \cdot \mathrm{IV}_{\mathrm{b}}$ とよんで扔くことにする.

古砂丘 I 下部洪積統の都濃津層上部 ${ }^{4)}$ の風成砂 層がこれに当り, 浜田市北方の国府町国分付近に露 頭がみられる．表層は赤土化が著しく赤色 $7 \cdot 5 \mathrm{R} 5 / 6$ ないし赤褐色 5 YR 5/8 を呈している.なおこの期 の段丘は高位段丘の上位面に相当するものと考えら
れている5゙,

古砂丘历下関市の安岡中学校をのせる丘がそれ で，高位段丘の下位面が開析されて孤立丘化してい る. 上部の層厚 $15 \mathrm{~m}$ 内外が風成砂層からなり, 表 居部の $3 \mathrm{~m}$ ばかりが赤土化作用をうけて赤色 $7 \cdot 5$ 4/6ないし明赤橙色 $10 \mathrm{R}$ 6/8 を呈している. この期 の段丘形成の輸畐の最下部に当る北隣豊浦町の地層 から前期旧石器文化に属する水晶石器が大量発見さ れているところから推して ${ }^{6)}$, この安岡古砂丘は $M / R$ 間水期に形成されたことが推考せられる.

古砂丘 $\mathrm{III}_{\mathrm{a}}$ 上部洪積統からなるこの地層は, 古 砂丘のうちで最も広く発達した砂丘で日本海岸の各 地にみられる7。西日本では鳥取古砂丘をはじめ丹 後古砂丘, 長浜古砂丘層 I, 綾羅木古砂丘や玄海砂 丘の大城古砂丘砂層などが好例である.この段丘は 編年上 $\mathrm{R} / \mathrm{W}$ 間水期のものと考えられ ${ }^{8)}$, 段丘の上 部にのる砂丘の最上部には微量の小亜角磁を含む粘 土化した赤土層があって，ここから前期旧石器の特 徵をもつ綾羅木 I 文化の石器を多人検出している ${ }^{9)}$. 古砂丘 $\mathrm{II}_{\mathrm{b}}$ 玄海砂丘の芦屋古砂丘にみうけら れ(0)，表層は赤土化作用をうけているがその程度が 弱く褐色 7•5YR 5/8 呈している. 砂丘が形成され た時期は, $M / R$ 間氷期のクライマックスを過ぎて第 I 亜水期にいたるまでのころと考えられ，赤土化は ゲトワイゲル間氷期に当るころではないかと考えら れる(1).なおこの期の古砂丘は，今のところ玄海砂 丘だけにみられる。

古砂丘IV 玄海砂丘にみられる鳥栖口ームの上位 に堆積した厚い風成層で ${ }^{12)}$, 表層は赤土化作用をう けて赤褐色 5 YR 4/6 を呈している. 層位から考え $\tau$, 砂丘の形成時期が, 鳥栖口-ムと Würm 氷期

4）三位秀夫（1965）：海岸砂丘の形成について，第四紀研究，4の 1 .

5）三位秀夫（1966）：日本海沿岸における海岸砂丘の問題点. 日本地質学等総合論会資料.

6) 小野忠泡（1968）：山口県磯上遺跡の水晶集積址と旧石器. 考古学研究，14の 4.

7）高田平原研究グループ（1965）：高田平原北部の第四系. 新潟大学教育学部高田分校紀要 9. 柏崎団研グループ (1965)：柏崎平野の第四系, 新潟大学教育学部高田分校紀要 10.

8）河野通弘・高橋英太郎・小野忠泡（1965）：本州西端部海岸の洪積層とその問題. 山口大学教育学部研究 諭叢 $14,2$.

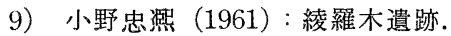

10）郷原保真・新堀友行・鈴木康司・野村 哲 -小森長生（1964）：北九州の第四紀に関する諸問題。資源研 彙報，62，新堀友行・郷原保真・野村 哲（1964）：北九州の玄海砂丘の意義一そのレス状層について一 にしるされた「暗色泥質帯」に当る。

11）松井 健氏の教示による.

12）上掲論文郷原保真ほか（1964）抢よび新堀友行ほか（1964）にしるされた「古砂丘II層（島郷砂曆下部） に当る. 


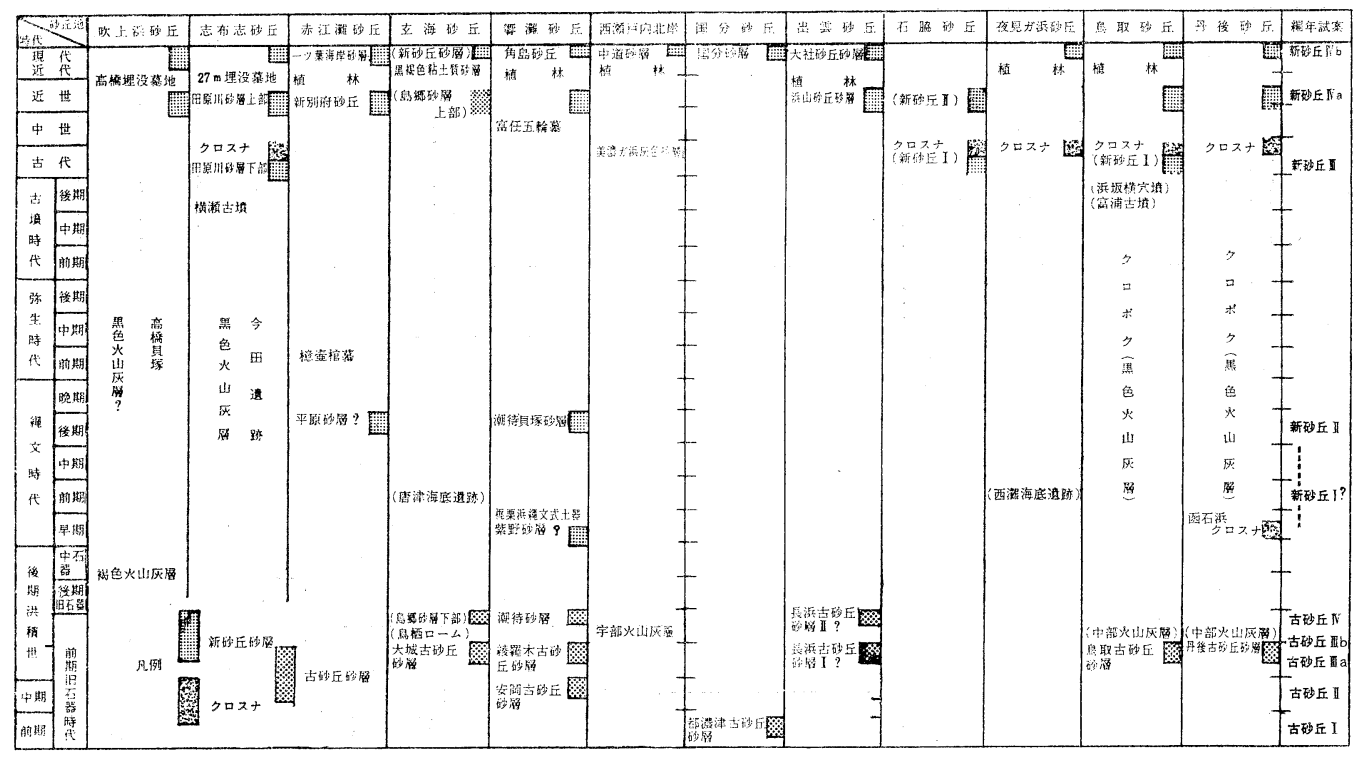

第1図西日本の主要砂丘編年試案（1968. 11） 図中の（）は既往の名称

のクライマックスの間に当るところから，赤土化は パウドルフ間水期に相当するものと考えられ，響灘 砂丘の中位段丘の下位面の潮待砂層や, 出雲砂丘の 長浜古砂丘砂層の川が対比できそうである.

新砂丘 I 下関市安岡半島の紫野遺跡 ${ }^{13)}$ にるご とく，段丘面の遺構の中部に繩文早期の遺物を含ん で堆積している黒砂化した風成砂層や，鹿児島県志 布志砂丘の第 I 砂丘 ${ }^{14)}$ などがそれで，繩文早期から 中期の間のある時期のものと考えられるが，資料が そしいので形成時期の確かな文化小期をつきとめる ことが困難である.

新砂丘 IIこの砂丘砂層も薄い飛砂層で，丘状を 呈するまでに発達していない、下関市の潮待貝塚 ${ }^{15)}$ をおう薄い風成砂層がこれに当るが他に発見例が少 ない，その形成時期は，砂丘砂の上面に古墳後期の 砂層がおおが貝塚中に砂丘砂が吹き込んだ状態を示 すところから推して，繩文後期かそれに近いそれに つづく時期と考えられる.小規模のうえ発見例が少
ないので砂丘形成期として 1 時期を設定するのは早 尚とは考えたが今後の発見が期待できるので暫定的 に仮設した。

新砂丘III 上位にクロスナ層がおう丘状の風成砂 層で，地層の層位や遺物の存在から奈良・平安時代 ごろのものではないかと考えられる，豊島らが指摘 した「新砂丘 I J $\rfloor^{16)}$ がこれで, 鳥取海岸の浜坂と石 脇や青井などでみうけられる。この砂丘砂は黄褐灰 色 10YR 5/2 で，ルーズなわりに砂丘面の保存がよ く，しかも上層のクロスナ層に漸移しているところ からその堆積時期がクロスナ層形成の直前であるこ とがわかる。

新砂丘 $\mathrm{IV}_{\mathrm{a}} \cdot \mathrm{IV}_{\mathrm{b}}$ 中世の末から近世以降に発達 した新砂丘は古砂丘に似た巨大な丘状地形をなし， 形成の時期によって $\mathrm{IV}_{\mathrm{a}}$ と $\mathrm{IV}_{\mathrm{b}}$ の 2 期に分けられる。 $\mathrm{IV}_{\mathrm{a}}$ は中世末期から近世にかけて形成され，江戸中 期から防砂林による固定化が成功し，江戸後期から 明治中期ごろまで飛砂が鎮っていたことが知られて

13）小野忠㜯（1961）：紫野遺跡. 山口県文化財概要 4 .

14）大矢雅彦・市瀬由自・和島誠一（1959）：志布志湾岸の平野地形 第 1 報 海岸砂丘を中心として、資源 研量報， 49 .

15）小野忠潶（1961）：潮待貝塚. 山口県文化財概要 4 .

16）豊島吉則・赤木三郎（1965）：鳥取砂丘の形成について。鳥取大学学芸学部研究報告，16の1. 


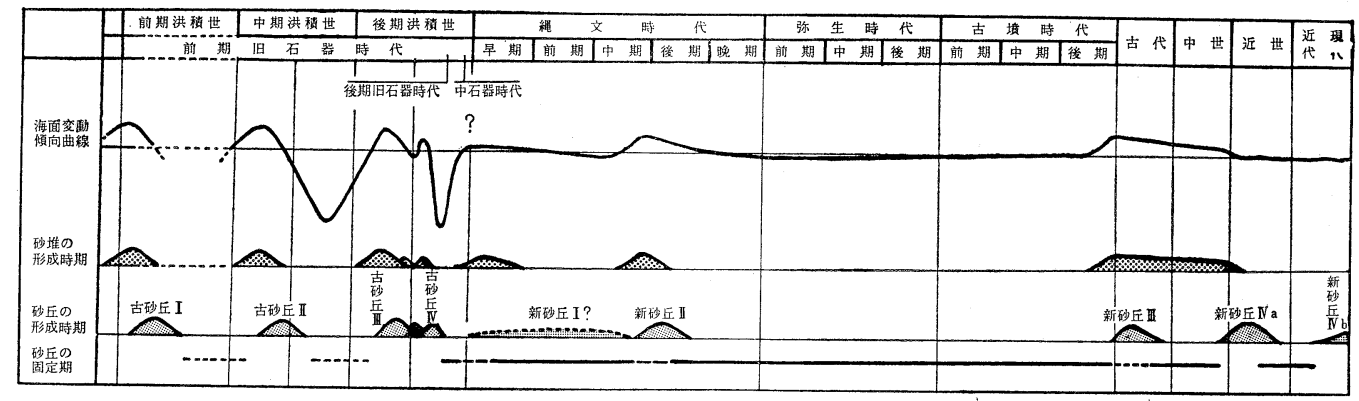

第 2 図西日本の砂堆と砂丘および砂丘固定期の概念図 (1968. 11)

いる ${ }^{17)} \cdot \mathrm{IV}_{\mathrm{b}}$ は明治後半から激 しくなった飛砂でっくられた最 も新しい砂丘で, その活動は今 日におよんでいる ${ }^{18)}$. 両期の砂 丘は全国的に点在し，この時期 が沉日本的な飛砂期であること を示唆している.

\section{III 海岸砂丘の形成に関連す る諸問題}

1. 古砂丘と新砂丘古砂 丘は Würm 氷期の前半以前に

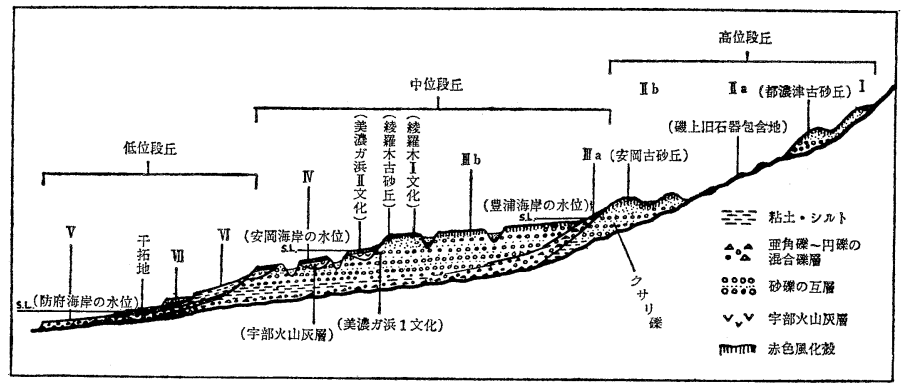

第 3 図中国地方西部の海岸段丘と古砂丘および旧石器出土層 準の相当位置説明図（1968.11）
形成され，いずれも表層が赤土化しているので一見 して新砂丘と区別することができる. 広義の砂丘の 形成期は合せて大小 10 回であるが，丘をなす風成 砂層という概念からすると, 古砂丘が 4 回, 新砂丘 が 3 回で 7 回ということになる.

2. 砂堆と砂丘との関係 古砂丘の多くは下部 の海成砂礫層の上にのり, 海岸の砂堆が砂丘の砂の 供給源であることを示し，それらの形成時期との関 係は第 2 図のとおりである.

3. 形成時期とその地域差 砂丘には汎日本的 なものと局地的なものとがあって，その規模も時代 と地域によって若干の差異がみうけられる.九州島 では，新古砂丘の形成時期のズレから $\mathrm{R} / \mathrm{W}$ 間水期 以後, 南北九州のシーソー的な垂直的変動があった ことを指摘することができる.
4. 海岸段丘と砂丘の序列掞よび赤土との関係 中国地方の西部では海岸砂丘の編年的序列と古砂丘 の形成時期が一致し, 砂丘の新古や形成時期と赤土 化作用の程度がほぼ照応している. 古砂丘の表層に ついてみると, I は赤色 $7 \cdot 5 \mathrm{R}$ 5/6 赤褐色 $7 \cdot 5 \mathrm{R}$ 4/6 4/8， II が赤色 7•5R 4/6 4/8， III a は赤褐色 5 YR5/6〜 5/8，IIIb は明褐色 7•5YR 5/8, IV は赤褐色 5 YR 4/6〜 5/6 である (第 3 図).

5. 新砂丘の固定 新砂丘の表面には黒色火山 灰層や腐植土が堆積して固定化し，いわゆるクロボ ク ${ }^{19)}$ やクロスナ層 ${ }^{20}$ を形成している.クロボクの堆 積は砂丘が固定していた繩文時代から弥生時代にか けて，また標識的なクロスナは砂丘の移動がとまっ ていた中世に堆積したことを包含する遺跡や遺物が 示している.

17）大西正巳・伊藤正史（1960）：砂丘の生いたち，大明堂.

18）大西ほか上揭書.

19） 日本第四紀学会（1963）：テフロクロノロジー特集号. 第四紀研究，3の1２.

加藤芳朗 (1964)：腐植にとむ土壌（「黒ボク」土壌）の生成に関する問題点. 第四紀研究， 3 の.

菅野一郎（1965）：火山灰土といわゆる黒ボク土の分類と命名．ペドロジスト，9の 2.

20）豊島吉則・赤木三郎（1965）：鳥取砂丘の形成について. 鳥取大学学芸学部研究報告, 16 の 1 . 


\section{ON THE FORMATION OF COASTAL DUNE FROM THE POINT OF VIEW ARCHAEOLOGICAL GEOGRAPHY -IN THE CASE OF WESTERN JAPAN-}

\section{Tadahiro ONO*}

The subject for the writer to deal with is to take up coastal dunes as living stage for human beings from the view-point of archaeological geogrphy, to define the period of dune formation, pointing out several problems extractible from their developing processes. 1. Periods when coastal dunes are formed : 5 epochs are found as to the diluvial and the alluvial formation. We name the diluvial dunes; the ancient dune I, II, IIa, IIIb, IV, the alluvial dune; the new dune I, II, III, IVa, IVb.

The ancient dune I is found to have been formed in the first-half of the diluvial epoch, the ancient dune II; in the middle, and the ancient dunes IIIa, IIIb, and IV; in the latter half respectively. The new dune $I$ is proved to have been formed at some time between the Preearlier and the middle period of "Jōmon"; The new dune II, in the later part of "Jōmon", The new dune III, from the end of the ancient times to the middle age; new dune IVa, from the end of the middle age to the modern age; IVb, from the end of the Meiji Era up to present.

2. Traits characteriring the ages each dune was formed:

1) In the case of Western Japan, ancient ones are all acted by the red soil according to its color changing and turned into, "Red Dune". New dunes are of light yellow or grayish yellow color, some are of dark sand or black soil layer. They are easily distinguishable at first sight. Largely grown ones are; the ancient I, II, IIIa, IV and the new dunes; IVa and IVb.

2) Dunes are supplied with their sand carried by waves from bars or beachridges. Hence close connection between both.

3) As to the periods they are formed, there are two kinds; pan-Japanese and regional, and therefore it proves necessary to carry on our research in consideration of these two phenomena.

4) The characteristic relationship between the period of coastal terraced formation and that if ordinary dunes;

The ancient dune I (Tsunozu ancient dune) forms the upper surface of the higher terrace.

The ancient dune II (Yasuoka ancient dune) forms the lower surface of the higher terrace.

The ancient dune IIa (Ayaragi, Tottori, Daijyo ancient dune) forms mid-surface of the middle terrace.

The ancient dune IV (Ashiya ancient dune) forms the lower surface of the middle terrace.

5) In the case of Western Japan, the degrees of the red soil changing process in the surface layer of the ancient dunes make striking contrast with the period of each terraced dune formation. It serves, therefore, for the indications to decide the period of ancient dune formation.

Geographical Review of Japan $42-3$ 1969. * * Yamaguchi Univ. 
6) The period when wind-carried sand forms dunes is relatively short, and there appear the green grass and woods or forests during the period when the sand settles down to become established dunes, and then come human beings to live there. It is, therefore, possible to make a rough estimate of time for its formation.

コメント 1

\section{鳥取砂丘研究の結果加ら}

大 西 正 已*

私は約 20 年前頃から「洪積世の生成と考えられ る火山灰土層下の古砂丘と沖積世にできた新砂丘」 について，鳥取砂丘を中心に山陰全域の海岸砂丘研 究をやってきた。今秋の大会で小野・三位・遠藤の 3 氏がそれぞれの角度から科学的で新鮮な研究を発 表され，教えられるところが大であった。しかし砂 丘研究にはかなり多くの問題点を残していると思う。

(1）1つの砂丘の中にも異った性格をもつものが ある. 地形区分による生成・移動の相違を掘りさげ る研究も必要ではなかろうか。

(2) 海岸段丘研究の進展が古砂丘形成と段丘形成 とを混同することが多い。この面の研究も必要では ないかと思う。

（3）火山灰土被覆前の古砂近は雨水を浸透したの で表面唚蝕は少なかった．古砂丘の起伏と風の営力 の関係を検討すべきだと考える.

（4）水成か風成かの判定には種々な問題が残され ている．特に層理で判断することは危険である．風 の強弱・湿度により砂丘表面や断面は変化する．海 岸砂丘の場合, 水平層理は風成の方が可能性が大で あるなど，砂と環境との関係の研究も必要であ万弓。
（5）北陸の芦原・片山津台地（古砂丘）を被覆す る赤色土が火山性土塞であることが最近判明した。 従来各地で砂丘風化の赤色表土だと考えられたもの が火山灰土ではなからうか。 また黄土の降下堆積な どの問題が残る.

（6）洪積世の降灰はひとり関東ロームばかりでは なく，山陰・北陸はもちろんのこと日本的規模の火 山爆発時代が考えられる。

（7）新砂丘を区分するクロスナ層についても，冷 温湿潤，腐植混入のみでなく，降灰・黄土などとの 関係を考虑して研究すべきだと考える.

（8）地盤の隆起（海退）が砂丘形成に影響するこ とは当然であるが，風の強弱・風向の変化が最も重 視されなくてはならない，気候変化の編年が研究さ れてよいと思う。

（9）吹雪の堆積・風蝕形態が砂丘のそれと類似し ている，周辺の地形・風に対する抵抗物との関係な どからも形成過程と変化を考えることができる.

(10) 古砂丘と新砂丘との組合せを見ると複合接続 型 (大社), 複合型 (鳥取), 分離接続型 (丹後), 完全分離型（北陸）などに分類することができる.

コメント 2

\section{久美浜砂丘研究の結果から}

\section{水山高幸**}

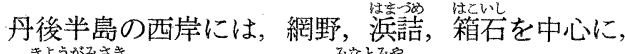
北の経力岬の西方から, 西の湊签まで, 主として第 三紀層よりなる岩石海岸に，小規模な新しい砂地形 が断続している。すでに小谷毊交（宫津高校）が 3
篇，坂口慶治（立命館大）が 1 篇，徳田 新・高山 孝（峰山高校）が 1 篇の報文をまとめ，その 1 部は 公表されている．それらと筆者の補足調查の結果と をあわせると，砂地形の構成物質は，土袞化したク

* 鳥取西工業高等学校

** 京都教育大学 
ロバンド (クロズナ?), シロバンド, アカバンド （火山灰起源のロームまたは赤色古土㖶 ? ）が 1 セ ットの地層をなし, それを境にして, 上部砂層と下 部砂層にわけられる. 上部砂層の堆積相は風成の特 色を多くそなえ，水成を疑う特色を欠いている．ゆ るやかな斜面に沿って，海抜 $100 \mathrm{~m}$ くらいまではい 上っているところがある. 厚さはうすく, 現在も飛 砂がみられる部分と, 人工で固定されている部分と がある(新砂丘?). 下部砂層は, 上野, 浜詰より 西方のものは, 水成と考えられる特色が多く, 礫や サンドパイプを含むところもある. 網野より北方の ものは, 風成の特色を多くそなえ, 水成を疑う特色 を欠いている（古砂丘？).土堙化した地層は, 西 の葛野付近の海抜 $3 \mathrm{~m}$ から, 北の小浜の海抜約 $50 \mathrm{~m}$ まで，かなり著しい高度差がある. 土壌化した地層 の性質も，そのせまい範囲内でかなり著しい地域差 を示している. そこに包含されている文化遺物にも かなりの時代差がある. なお，箱石付近では, $15 \mathrm{C}$,

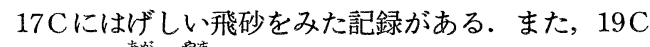

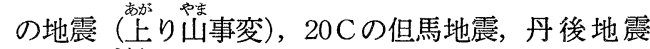
の時, 河梨断層線などに沿って, メーター単位の地 盤の変位がみられ, 付近の地形, 地層に局地的擾乱 をみたことが推定されている.さらに，この地域全 体を通じて，東高西低の形式の地塊ごとの，地盤運 動による変位が推定されている.

したがって， ${ }^{14} \mathrm{C} に よ る$ 年代測定の資料や文化遺 物の採取地点の選定, 土壌化した地層を地層対比の 鍵層として利用する方法, 砂層を新砂丘, 古砂丘と 認定する方法など，時代論に中心をおいて議論する 場合，各露頭間の共通性を抽出するに先立って，そ れぞれの地域差や，砂地形の形成あるいは砂層の堆 積の環境, 営力, その物質の供給源などの古地理に ついて，微細に検討する必要がある.すでに一般化 された第四紀地史のこまかい部分まで, ある程度固 定させて，既知項とみなして，それにあてはめると， 観念論に陉いる危険が感じられる.

コメント 3

\section{先史・歴史地理学の立場から}

\section{藤 岡 謙 二 郎*}

1. 日本の砂丘研究は面積的に広範囲を占める新 砂丘期の編年に今後重点がおかるべきで，この方面 の考古地理的研究が遅れている. 丹後箱石の場合も 基盤の第三紀層の露出はみられず，佐濃谷川の西流 はやはり小牧説のごとく, 新砂丘の進行によるので はないか.つぎに先史時代に集落占居の場となって から以後はどうなのか. 砂丘上の古墳分布について も関心が必要. 発表者は中近世の墓碑のことを述べ たが，筆者も佐渡国府が真野湾口の砂丘上にあって， その一部の小高いところが，展望に利用されたと考 えた. 砂丘の固定化作業は近世の文献にみられるが， 近世に行ってから砂丘の進行が進んだのであるかど うか. 古砂丘形成の地質地形学的研究のほか，歴史 時代の新砂丘形成の問題が大切である.

2. 海岸砂丘の研究は風下側の潟湖の消長と併行 して行われるべきである.鳥取県湖山湖の中央に浮 かぶ青島遺跡の原景観はどんな具合であったのだろ
ろか. また石川県の柴山潟湖畔から弥生・繩文の接 触土器を出土する遺跡を筆者は発掘した.つぎに箱 石浜大遺跡のように旧河口に外海をのぞむ遺跡の理 解には, 河川上流の後背地との交通位置の関係が考 慮されなければならない，砂丘地のみを付近地域か ら隔離して考察さるべきではない.

3. 黒スナ層が問題になるが，今後は第 1 類第 2 類等と細分類が必要である. そのためには，土壌検 定表のように，その炭化度の色彩尺度を決める必要 がある. また黒スナの濃淡が地域によって異るのか, それとも砂丘固定期の年代差によるのかといった点 を，うちに包含する植物化石や遺物片等の分析を勘 案して考察さるべきである. この場合考古学的資料 のみにたよりすぎてもならないし, 自然的作用のみ と考えてもならない.これらの点もポーランドの砂 丘遺跡の研究で行っている花粉分析その他の植物学 的研究も参考にすべきである.

* 京都大学 
コメント 4

世界の砂丘

\section{多田文男*}

中・北欧では，大陸氷の運んで来た砂の研究が盛 である.これを研究対象によって分けると，第 1 は 風によって空中に飛ばされ, それが周縁地帯に堆積 した微砂即ちレス及び砂質レスの研究であり，第 2 は風によって地表を転がって砂丘をつくった砂の研 究である. 本日, 三位博士は黄土の影響を受けた玄 海砂丘に就いて論議されたが，これが果して地表を 転がって来た砂からなるか，空中を飛んで来た砂か らなるか，慎重に検討す可き問題である. 第 2 の砂 丘は内陸砂丘と海岸砂丘とに分けられるが，今日論 ぜられた海岸砂丘は中・北欧では北海に沿った和蘭 の沿岸洲上とバルト海岸のクーリシュ砂嘴上の砂丘 とが精査されている.ここでは, 共に今日論ぜられ た日本の砂丘と同様に泥炭層に蔽われた埋没古砂丘 があり，その上にのる新砂丘は腐植質黒砂を境とし て新・旧砂丘に分けられている. 砂丘の生成時期は 砂の供給の盛衰期によって決まる. de Geer の第四 紀年代表を見ると，中・北欧の砂丘の主生成期を氷 期としているが，これは砂の供給が氷河によって最 も盛なので当然である．供給される砂が風で移動す るのは砂が乾いている時と植生がなくて裸砂となっ
ている時とである．砂が乾いているのは中欧では海 退によって洲が高くなった時である.その海退は 1) 地殼運動によって土地の隆起した時，2）大陸氷の 後退に伴ならアイソスタチックな土地の隆起した時, 3）気候寒冷化に伴うユースタチックの海水面の低 下した時に起る。アイソスタシーによる隆起は狭い 地域内でその量，その時期を異にする．従って砂丘 の生成時期, 量も狭い地域内でも示差的である. 北 海沿岸の狭い地域間でもポーランドとシレスウィ ヒ・ホルスタイン間でも砂丘の生成時期・量を異に しているのである，本日の三位博士，遠藤修士のお 話だと日本全国の砂丘が同じ時期に盛衰があり，砂 丘の活躍期と固定期とが同時代にあると論じられて いるが，日本の様に地殼運動の示差的である所では， その影響よりも, 植生の盛衰, 換言すれば気候変化 の影響が大きいのであろらか. 又今日の発表では玄 海砂丘や鳥取砂丘に水成砂から出来ている砂丘があ る由であるが，かかる水の作用による堆積砂丘を将 して，砂丘と呼んでよいものであろうか．“砂丘” の定義を変える可きでなかろうか.

\section{2）砂丘の形成営カ……新潟砂丘を中心として}

\section{新潟北部海岸における飛砂}

一一砂丘生成の営力に関する研究——

\section{荒巻孚**}

\section{まえがき}

風によっておこる土砂の移動を飛砂と呼び，飛砂 によって生成される丘状の地形を砂丘という．飛砂 の研究は大陸地における大規模な sand storm を対 象とした砂丘や風漣の研究を中心にして進められて
来た．しかし，最近になって風による砂の移動が経 済的に大きな損失を考えることが認識されるように なり, 流体力学の問題としてかなり進んだ飛砂研究 が行われるようになってきた．特に，日本では，従 来, 農業災害に関連して飛砂研究が進められてきた が, 最近では臨海工業地帯の建設に伴う港湾の設計

\footnotetext{
* 駒沢大学

** 専修大学経営学部
} 
や維持管理の立場から飛砂の問題がとりあげられつ つある.

現在までの飛砂研究をみると, 砂の移動のメカニ ズムは実験室あるいは野外での研究を通じていまだ 解明されていない. とくに, 砂の移動量・砂粒子の 性状・風の状態などの相互関係について, 野外での データが一層必要である1 ${ }^{1)}$ 従来の飛砂理論は大き く二つのグループに分けることができるが，一つは 拡散理論にもとつくくのであり, 他は砂粒子が砂面 付近での跳躍運動を伴って風下側に移動するという 仮定にもとづくものである. 前者の代表的例は Exner 理論であり，後者の例は Bagnold 理論である. この中で Bagnold によれば, 砂の移動は匍行・跳 躍・浮遊の三つに分類できるといわれるが，砂粒の 大部分は砂粒と空気との密度差が大きすぎるため, 浮遊状態で移動することはほとんどみられないであ ろ ${ }^{2)}$.

ここでは, 新潟北部海岸で行った飛砂調査の結果 にもとずき，その現象を説明する ${ }^{3)}$.

\section{調查地域の概観}

調査は新潟県北部の阿賀野川から加治川分水路に 挾まれた $15 \mathrm{~km}$ の海岸線を対象として行った. 海岸 に隣接する背後の砂丘には亀塚浜・太郎代浜・島見 浜の集落があり，ここは南浜海岸とも呼ばれている. 海岸は典形的な砂浜海岸で, 浜には礫がわずかに点 在するにすぎない. 海岸線は平滑で，内陸側にやや 喰込んだ放物線状の曲線型をなす．海岸の背後には 前述の砂丘のほか, 十数列の砂丘・砂堆が発達し, その主軸の方向は海岸線にほぼ平行している4).こ の中で，前述の集落をのせる砂丘が最も比高が高く，
その值は $20 \mathrm{~m}$ をこえる. これらの砂丘・砂堆の列 群は海岸線から内陸にむかって約 $4 \sim 7 \mathrm{~km}$ の幅 ${ }^{5)}$ の地域に発達する.この地域から背後には福島潟・ 紫雲寺潟の干拓地を含めた低湿地がひろがり，更に 内陸には加治川のつくる扇状地が広く展開する.

今回の調査の目的は太郎代浜付近を港口として砂 丘地帯に建設される新潟東港（新潟工業港）とそれ に伴って開発される工業地帯の造成に関係するもの である.とくに，海岸構造物の設計に関する問題， 造成後の飛砂に対する維持・管理の問題，工業地帯 に誘致する適種工業の選定の問題，港湾建設による 浚渫土砂の処理の問題などがあげられる.

\section{調查方法}

調査は昭和 37 年冬季から 38 年春季にかけて行わ れた。 その方法を簡単に述べるとつぎのようであ

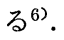

\section{1 飛砂調查}

A）飛砂採集器 匍行・跳躍して移動する砂粒を 対象とする. 採集器は $\mathrm{A}$ 型および $\mathrm{B}$ 型の 2 種類を使 用したが， $\mathrm{A}$ 型は今回の調査にあたって特に考案し たものである.A型採集器は採砂口の幅 $5 \mathrm{~cm}$ ，高 さ $1.4 \mathrm{~m}$ で，飛砂の垂直分布が知られるように内部 は13 層に仕切られている. 一方，B型は採砂口の 幅 $1 \mathrm{~cm}$, 高さ $1 \mathrm{~m}$ で区切りのない全層式である7). $\mathrm{A}$ 型採集器 5 基， $\mathrm{B}$ 型採集器 2 基を主に海岸地に設 置した。

B）飛砂捕集塔 空中を浮遊しながら移動する飛 砂を対象とする. $5 \mathrm{~m}$ の高さの塔に $1 \mathrm{~m}$ 間隔で 10 $\mathrm{cm}$ 四方の捕集板をとりつけて観測した.これらは A 型採集器の設置地点に併設した.

C）飛砂測定ポール 飛砂による地面変化を簡単

1) Horikawa S. \& Shen, H. W. (1960): The Sand Movement by Wind Action-On the Characteristics of Sand Traps-. Beach Erosion Board Tech. Mem. No.119.

2）砂粒の運動をみると，その大部分は跳躍による. Bagnold の砂漠での実測によれば，転動して移動する 砂量は $15 \sim 25 \%$ で残りは跳躍によるという. 石原らによる鳥取県網代港の例では，転動する砂量は $6.5 \sim$ $16.6 \%$ にすぎないという.

3）新潟北部海岸の飛砂調査にあたっては, 立正大学石川与吉教授, 東京教育大学町田 貞教授, 鳥取大学 豊島吉則助教授，立正大学高山茂美助教授の御協力を得た。調査の機会をお与えいただいた運輸省第一港 湾建設局の関係各位と併せて深く感謝申し上げる.

4）町田 貞・荒巻 学 (1965)：阿賀野川右岸地域の海岸砂丘と砂堆について. 東京教育大地理学研究報告 IX, pp. $227 \sim 243$.

5）阿賀野川寄りの南側の地域ほど，その幅は広い.

6）詳しくは新潟東港飛砂調査報告書（運輸省第一港湾建設局, 昭和 39 年 1 月，1 180 頁）を参照して頂き たい.

7）堀川清司らが米国の海岸侵蝕局の依託をうけて考案したものである. 
飛吵採集器 $(A$ 型)

- 飛砂採集器( $B$ 型)

我砂捕集塔

日飛砂測定ポール

$\Delta$ 長期気象観測

$S$ 島見浜 $T$ 太郎代浜 $K$ 亀塚浜

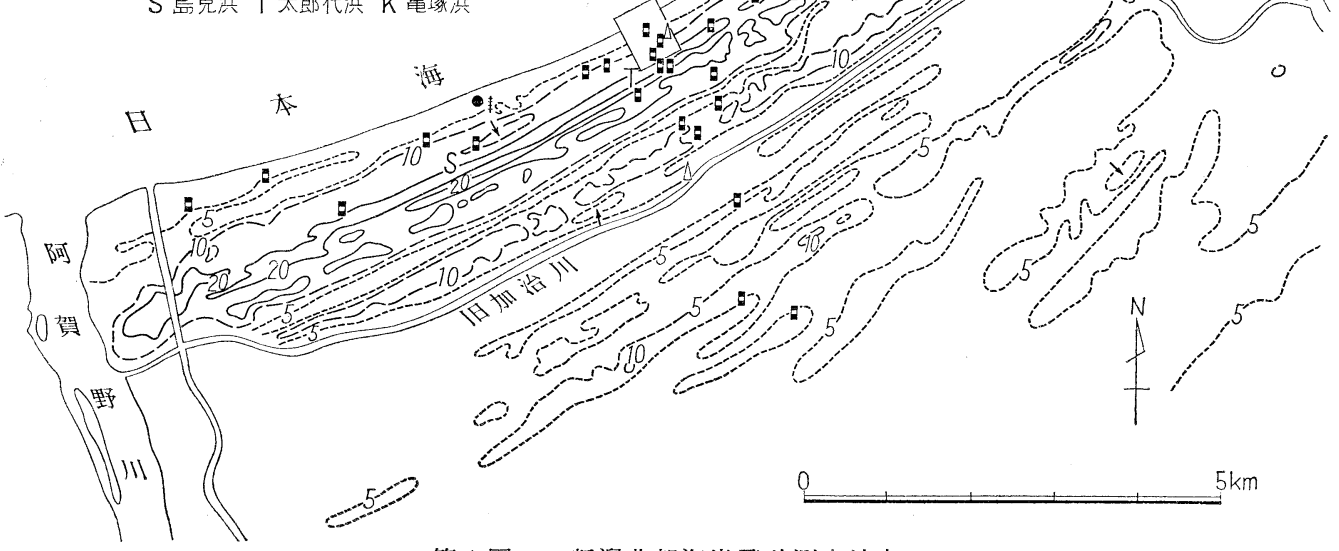

第 1 図新潟北部海岸飛砂測定地点

に知る目的で, 高さ $1 \mathrm{~m}$ のポールを地面にとりつけ, 相対的な砂の移動量について観測した．ポールの設 置地点は内陸部も含めて 30 ケ所に及んだ.

2 風向・風速測定

A）長期観測 太郎代浜で 1 ケ所 2 測点（測点の 標高 $10.5 \mathrm{~m}$ および $25.0 \mathrm{~m}$ ), 海岸から内陸に約 1.8 $\mathrm{km}$ 距った旧加治川の河岸に 1 ケ所（測点の標高 $10.5 \mathrm{~m})$ の計 3 測点で, ロビンソン風向・風速計を 使用して年中，観測した.

B）一般観測 飛砂の観測を行った地点で，その 周辺部に数ケ所ずつ測点を設け, 随時, 風を測定した.

これらの調査地点を一括して図示すると, 第 1 図 のようである.

\section{調查結果に対する考察}

1 始動風速 砂粒は風速がある值に達すると 動きはじめるが，砂粒の状態によって始動風速値は 異るであろう.一般に乾燥砂の場合, 粒径 $0.3 \mathrm{~mm}$ の

\begin{tabular}{|c|c|c|c|}
\hline \multicolumn{2}{|c|}{ 第 1 表 } & \multicolumn{2}{|c|}{ 飛砂の始動風速值（新潟北部海岸） } \\
\hline \multicolumn{3}{|c|}{ 地面砂の状態 } & 始動風速 $U_{100}(\mathrm{~m} / \mathrm{s})$ \\
\hline 強 & 雨 & 中 & $11.8(\fallingdotseq 12.0)$ \\
\hline 弱 & 雨 & 中 & $9.8(\fallingdotseq 10.0)$ \\
\hline 降水直後 & \multirow{3}{*}{$\begin{array}{l}\text { 含 } \\
\text { 水 } \\
\text { 量 }\end{array}$} & 多湿 & 8.5 \\
\hline 未 & & 湿 & 7.0 \\
\hline 檽 & & 乾 燥 & $5.2(\fallingdotseq 5.0)$ \\
\hline
\end{tabular}

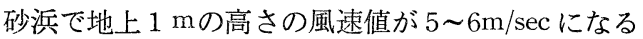
と砂が動きはじめるといわれている8). 当調査地域 の海浜砂はその大部分が珪長釷物によって構成され， その中央粒径は前浜で $0.37 \mathrm{~mm}$, 後浜で $0.24 \mathrm{~mm}$ で あった.これらの砂を着色し, 砂の始動状態と風速 との関係を把えると，第 1 表に示される. 乾燥砂の 場合, 地上 $1 \mathrm{~m}$ 高さの風速 $\left(\mathrm{U}_{100}\right)$ が $5.2 \mathrm{~m} / \mathrm{sec} に$ 達すると動き始め, 雨中でも約 $10 \mathrm{~m} / \mathrm{sec}$ の風で始動 する. とくに, $12 \mathrm{~m} / \mathrm{sec}$ 以上の風が吹くと，どのよ うな気象条件の下でも飛砂が発生する ${ }^{9)}$.

8）石原藤次郎・本間 仁編 (1958)：応用水理学中 I, 丸善, p. 50 .

$9)$ 従来の研究をみると, 限界摩擦速度 $\left(\mathrm{U}_{* \mathrm{c}}\right)$ は砂粒の大きさ $(\mathrm{dmm})$ とその密度 $\left(\sigma \mathrm{g} / \mathrm{cm}^{3}\right)$ との積の平 方根に比例するが，この值 $(\sqrt{\sigma d})$ が 0.4 よりも小さくなると， $\mathrm{U}_{* \mathrm{c}}$ が却って大きくなるといわれる. また, 今回の結果を河田の式にあてはめ摩擦速度を推算して検討すると, 乾燥砂の場合には従来の $U_{* \mathrm{c}}$ と $\sqrt{\sigma d}$ との関係にほぼ一致する。しかし，降雨時のような異常気象の時には合致せず， $U_{* \mathrm{c}}$ の大きな值を 必要とする. 


\section{2 高さ方向の飛砂量分布}

河村は飛砂の垂直分布が指数型を示すと仮定して， 濃度分布と飛砂量分布を与える式を導いた ${ }^{10)}$.この 結果, 種々の仮定が入っているが， $\log q w$ (単位時 間・単位面積当りの飛砂量 $\mathrm{g} / \mathrm{cm}^{2} \cdot \mathrm{hr}$ ) と $Z$ (高さ $\mathrm{cm}$ ) とが直線関係にあることを明らかにした，新潟にお ける今回の事例をみても, 両者は直線関係にあるこ とが知られるが，高さ (Z) $20 \sim 30 \mathrm{~cm}$ を境にして， 係数を異にする 2 つ指数分布を示すようである. 地面から 20 30cm あたりまでの飛砂量の垂直変化 は著しく, とくに強風時にその傾向が強い11).

3 水平方向の飛砂量分布

汀線に直交する方向の飛砂量分布をみると, 浜堤 の背後では汀線付近における飛砂量とほぼ同量の飛 砂がみとめられるが，松林の生育する小砂丘をこえ ると飛砂が急減し, 汀線付近の飛砂量の約 $1 / 300$ 程 度にすぎなかった。

ポールによる地面変化の観察では，海岸付近での 地面変化が著しいが汀線から約 $2 \mathrm{~km}$ 離 れた旧加治 川より内陸部でも僅かながら変化する.このような 地面変化は流水の作用によるものがあろうが，ポー ルにとりつけた筫立ての前面の状況から判断して飛 砂による影響をみとめることができた。一般に海岸 地域では地面が侵蝕傾向にあり, 浜集落が存在する 砂丘から内陸部では堆積傾向にあった. 中でも砂が 乾燥する春季にそれらの傾向が明らかであった ${ }^{12)}$

\section{4 飛砂の粒度組成}

飛砂の粒度は海浜の地面砂よりも小さく, 淘汰も 良い.この傾向は地面から離れるほど明らかになる が, 粒度の垂直変化はそれほど顕著に認められるわ けではない.

飛砂の粒度（例えば $\mathrm{Md}$ ) は風速と比例関係にあ って，風速值が大になると，粒度も大きくなる．こ のことは風速が大きくなるにつれて粗粒砂の移動が
活発になることを示している，また，風速値が 10 $\mathrm{m} / \mathrm{s}$ を超えるような強風時には, 飛砂の粒度は地面 砂のそれとほぼ同じ值になる．したがって，10m/s 以上の風汃吹くと地面砂のほとんどが風によって移 動することが知られる。

\section{5 飛砂の鉱物組成}

砂粒は個々に磁性や比重を晎にするため，同粒径 の砂粒でも風による影響の受けかたが違うであろう. 今回の調查によると, 飛砂の中に含まれる磁性鉱物 の割合は地面砂よりも小さく，全体に石英・長石な どの無磁性鉱物の占める割合が大きかった。

鉱物組成からみた飛砂の垂直分布をみると, 全体 に地面から離れるほど僅かながら磁性鉱物の割合が 小さくなる．このような磁性砂の減少は砂の比重の 違いによるもので，上層ほど比重の大きい磁性砂の 輸送が少なくなるものと考える.このことから飛砂 現象を把える場合，砂粒子の大きさ・比重など，そ の性状を十分に把握する必要がある.

6 風速と飛砂量との関係

風によって輸送される砂量を推定することは極め

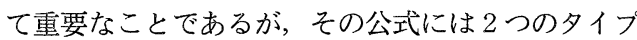
がある、1つは Bagnold が導いた公式であり，他 の1つは河村の公式である. Bagnold ${ }^{13}$ は砂が単位 幅の径路に沿って跳躍し移動すれば，単位時間・単 位幅あたりに輸送される砂の質量 $\left(Q_{W}\right)$ は単位面積 あたり単位時間に砂面から飛び出す砂の質量と砂粒 の平均跳躍距離との積によって表わされることを考 え，最終的につぎのような式を導いている.

$$
Q_{W}=C \sqrt{d / d^{\prime}}(\rho / g) U_{*}{ }^{3}
$$

ただし，Cは砂の混合状態によって変わる常数 (砂粒の混合状態により 1.5 2.8), d は砂の粒径, $d^{\prime}$ は標準となる砂の粒径 (この場合 $0.25 \mathrm{~mm}$ ), $\rho$ は空気の密度, $g$ は重力の加速度, $U_{*}$ は摩擦速度.

一方，河村 ${ }^{10)}$ (地面に墈く剪断力 $\tau$ が砂粒子の衝

10）河村竜馬（1950）：飛砂の理論と実測，防災林に関する調査報告．治山事業参考資料第 I 輯，林野庁，23 $\sim 34$.

11）地面から高さ $25 \mathrm{~cm}$ までの飛砂の垂直分布を $\log \mathrm{qw}=-a Z+b$ として，係数 $\mathrm{a}$ の值とその時点の風速值 との関係を求めると，一般に風速值が大きいほど係数 a の值は小さくなる.

12）理論的に，単位幅当り単位時間に或る断面を通過する砂の量と侵蝕される砂の量とを考え，飛砂のはじ まる原点を汀線にとると，砂面が侵蝕をうけるのは汀線のごく付近の地域にすぎないという．このことは 波で打ち上げられて堆積した砂が，海から吹いてくる風によって次第に奥地に運搬されてゆくことを意味 する。

13) Bagnold R. A. (1954) : The Physics of Blown Sand and Desert Dunes, Mathuen \& Co. Ltd, London, 64. 
突による剪断力と直接, 風によって起因する剪断力 の和であることを考え, 最終的につぎのような結果 を得ている.

$$
Q_{W}=K \cdot \frac{\rho}{g}\left(U_{*}-U_{* C}\right)\left(U_{*}+U_{* C}\right)^{2}
$$

ただし，Kは実験によってきまる常数（風洞実験 では $K=2.78), U_{* C}$ は限界摩擦速度.

これらの式を比較すると，基本的な考え方は両者 ともほぼ同じであるが，Bagnold の式によると， $U_{*}$ $=U_{* C}$ のときでも $Q_{W}$ が零にならない欠点があり, この点から河村の式がやや合理的であるといえる ${ }^{14)}$. しかし，いずれの場合にしても，常数は風洞あるい は野外での測定によって決める必要がある．この場 合, 風洞実験では実際とはかなりかけ離れた值が得 られょうし，野外では十分に信頼できる採砂器の設 計がむずかしいことから，その值を求めることがか なり困難になる.

このような問題はあるけれども, Bagnold は摩擦 速度 $\left(U_{*}\right)$ の代りに地面からの高さ $1 \mathrm{~m}$ の風速 $\left(U_{100}\right)$ を用い, $d=d^{\prime}$ と考え, 前式を書き換えて次式を得 た.

$$
Q_{W}=7.1 \times 10^{-3} C\left(U_{100}-4\right)^{3}
$$

ただし， $Q_{W}$ は単位幅・単位時間あたりの飛砂量 $(\mathrm{t} / \mathrm{m} \cdot$ day $), U_{100}$ は地上 $1 \mathrm{~m}$ の風速 $(\mathrm{m} / \mathrm{s}), C$ は砂 の混合状態によって変わる常数 $(C=1.5 \sim 2.8)$.

いま，今回の調査による結果を Bagnold の式に あてはめ，この式によく一致するようCの值を求め ると, 海岸地では $C=0.25$, 海浜の背後の砂丘地で は $C=0.0025$ ほどになる.すなわち, 当地域では 飛砂の多い海岸地でも, Bagnold の約 $1 / 10$ の值が 得られたにすぎない. 河田 ${ }^{15)}$ が鳥取砂丘で調べた結 果でも，Cの值は 1.0 以下に見込まれるようである. このことは一般公式を求めるにあたり地面砂の状態 や気象条件などについて，一層の配慮が必要性であ ることを物語っているといえる.

なお，飛砂量と風速との関係から，そのまま回帰 式を作ってみると，次のような結果が得られた。

太郎代浜海岸地 ${ }^{16)} \quad Q_{W}=6.573\left(U_{100}-5\right)^{1.963}$

$$
\begin{array}{ll}
\text { 島見浜海岸地 } & Q_{W}=7.537\left(U_{100}-5\right)^{1.903} \\
\text { 亀塚浜海岸地 } & Q_{W}=0.803\left(U_{100}-5\right)^{2.261}
\end{array}
$$
それぞれの海岸とも，風速の 2 乗にほぼ比例してい ることがわかる. また，風速と飛砂量との関係を図 上にプロットすると，点がかなりばらついており ${ }^{17)}$, 前述の地面砂や気像条件を考慮する必要がある.

\section{7 年間飛砂量}

今回の飛砂調查はその現象の顕著な冬期から春期 にかけて行ったが，風については年間を通じて測定 したので，その資料にもとづいて当地域の年間飛砂 量を推定する.まず，飛砂現象が見られたであろう 日を風や降雨などの気象資料から推定すると, 年間 飛砂日数 ${ }^{189}$ は 120 日前後となる. この日数は 1 年の 約 $1 / 3$ にあたる。

月毎の単位幅あたりの飛砂量をもとめると, 冬季 には月に $10^{4} \mathrm{~g} / \mathrm{cm}$, 春・秋季が $10^{3} \mathrm{~g} / \mathrm{cm}$, 夏季に $10^{2}$ $\mathrm{g} / \mathrm{cm}$ のオーダーとなり, 冬季は夏季の約 100 倍の 値を示した.

年間飛砂量は汀線付近の海岸地で $8 \times 10^{4} \mathrm{~g} / \mathrm{cm}$, 浜堤背後の地域で $7 \times 10^{4} \mathrm{~g} / \mathrm{cm}$, 砂丘前面の地域で $6 \times 10^{2} \mathrm{~g} / \mathrm{cm}$ となる. このことから, 阿賀野川と加 治川とに㣣まれた海岸地域での年間の総飛砂量は約 12万と推算される.なお，これら海岸からの飛砂は 海岸背後の松林付近でほとんど停止・抑留し，10-2 程度の值になる。

\section{あとがき}

地形学において砂丘調査をする場合, 単なる地形 的現象の記載や分類だけではその実態を把握するこ とはできない.したがって，飛砂現象は Bagnold も 指摘しているように，地形学，とくに砂地形を考え るうえで関心の深い問題である. 飛砂を研究するた めには，野外での観測のほか，風洞実験などによる 解析も必要となるが，地形学者は自分に都合の良い ような条件を設定して害験する物理学者や工学者の やり方を好まない風潮がある.このことは地形学者 が砂丘を含めた種々の地形の生成される場合，時間 的に長い過程の中で, 極めて複雑な要素によって作

14）堀川らによると，両者の式は風の強いときには，ほぼ同じような結果を得ると指摘している.

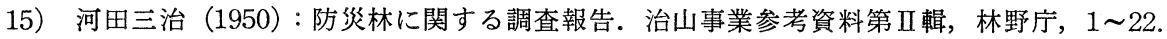

16） 太郎代浜の浜堤背後の地点では $Q_{W}=29.61\left(\mathrm{U}_{100}-5\right)^{1.052}$, 砂丘の前面では $Q_{W}=6.806 \times 10^{-2}(\mathrm{U} 100-5)$ 1.818 .

17）同じ風速でも乱れの強さがちがうこと，地面の乾湿の状態がちがうことなど種々の要因が考えられる.

18） 昭和 37 年 4 月から昭和 38 年 3 月までの期間. 
られていることを知っているからである. しかし， 砂粒の運動, そのものの椂態を知らなければ, 飛砂 のメカニズムを明らかにすることはできないのもま た事実である. 野外に抢ける飛砂研究と風洞実験な どによる研究が両立してこそ効果的な研究が約束さ れる。

一方, 従来の飛砂研究は内陸地に招ける砂の移動 を対象としたものが多かった．したがって海岸飛砂 について，新たな角度から検討する必要がある。と くに，わが国の場合, 経済的に価值の高い海岸地の
飛砂研究は今後積極的に推し進めるべきであろう. また，海岸地における砂の移動は極めて活発で, その量も多い，新潟北部海岸の今回の事例でも，海 岸地に打ける砂の移動は $8 \times 10^{4} \mathrm{~g} / \mathrm{cm}(1 \mathrm{~m}$ 幅あたり $8 \mathrm{t}$ ）となり，規模的に大きな地形を生成，または 改変する力となり得る. 砂丘生成の速度を考える上 で，この点を十分に配慮する必要がある.

なお，今回は特に考案した飛砂採集器を使用した が，今後更に捕獲効率の良い飛砂器の開発がのぞま れる。

\section{コメント}

\section{海浜地形の立場より}

\section{中 山 正 民*}

荒巻 学の新潟海岸における飛砂の研究によると, 風速の季節変化などから, 飛砂量は冬季に圧倒的に 多いことがわかる．このことを基本として考元ると， 日本海沿岸における砂丘の形成は, 主として冬季を 中心に進行することになる.これらの砂は，海浜及 び浅海から供給されるから，まず日本海沿岸におけ る海浜地形について，その季節変化をみた。

1） bar の变化 新舄海岸や金沢海岸における bar の分布や形態の季節変化をみると, 冬季（新潟 海岸 $7 \sim 3$ 月，金沢海岸 10〜 5月）における bar は, 長さが短かく, 幅が狭く, 高度が低く, 断片的であ る.これに対して夏季 (新潟海岸 $3 \sim 7$ 月, 金沢海 岸 5 ～10月）は, 長さが長く, 幅が広く, 高度は高 く，連続的である.

2) 海浜断面の変化 各海岸における水深 $10 \mathrm{~m}$ までの断面変化は, 冬季は侵蝕, 夏季は堆積傾向を 明膫に示し, それぞれの変化量はほぼ $1 \sim 2 \mathrm{~m}$ 程度 である.

3）汀線変化荒巻 学の石川海岸における結 果によると, 冬季は海浜高は減し，汀線は後退し， 海浜幅が減し単調な砂質海浜であるのに対し, 夏季 は海浜高が高まり，汀線が前進して海浜幅は広がり，
複雑な礫質の海浜となる。

以上の結果から，日本海沿岸の冬季は，海浜は狭 ばまり，水深 $10 \mathrm{~m}$ までの沿岸州を含む浅海は侵蝕 され，砂の供給量は相対的に減ずるものと考えられ る. 一方, 太平洋沿岸のうち筆者の行った鹿島・三 保・熊野浦・土佐海岸などの研究結果では, 日本海 沿岸とは反対に, 夏季は海浜は侵蝕, 冬季は堆積の 傾向を示し，冬季は砂の供給地域及び供給量が增加 するようである.

気候的には, 日本海沿岸は冬季降雪多く, 砂は常 に積雪で被われるか，湿潤な状態にあり，移動され にくい．これに対し，太平洋沿岸地域の冬季は乾燥 状態にあり，移動しやすい条件にある.このように 考えると, 冬季海岸から砂丘に対する砂の供給は, 太平洋沿岸のほうが日本海沿岸よりも有利な条件を もつ.

このようなことが，日本における海岸砂丘の発達 や規模にどのような影響を与えているかが問題であ ろう．筆者自身は日本海沿岸地域においては，いか に一時的に多量の砂の移動があっても，今日は砂丘 が発達するような時期でないと考える.

* 埼玉大学 
3）砂丘利用の技術的問題点之経済的問題点（農業生産を中心に）

\author{
砂丘地のカンガイと水資源
}

\title{
長 智 男*.矢 野 友 久*
}

\section{I え がき}

日本の海岸砂丘の面積は約 23 万 ha ある. 砂丘地 の土壤は, 有効保水量がきわめて小さいために, 土壤 水分の不足をしばしば生じ, 有機物の分解消耗がは げしく欠乏して，長年低い生産地であった，戦後畑 地カンガイ, 特に散水カンガイ法の技術の確立によ りカンガイ事業が盛んになり, 砂丘地特有の立地条 件を生かした高度の園芸地帯に変りつつあり ${ }^{1)}$ ，さ らに近年は労働生産性向上のために直場整備事業が 行なわれつつある. 今後はさらに林地や不毛地の利 用が促進されよう.ここでは砂丘砂の物理性とカン ガイの必要性, カンガイ方式とその発展, 地下水資 源などについて述べ，今後の研究課題につき触れた.

\section{II 砂丘地の土壌水分とカンガイ}

日本の砂丘地は, 外国の砂漠とは異なって, 湿潤 気候下にあるために，農作物の有効根群層（カンガ イ用水補給の対象となる根群の存在する土層) は約 $40 \sim 60 \mathrm{~cm}$ 位までであり，この層の水分の管理の如 何によって，農作物の収量と品質が大きく支配され る. 砂丘地の土壤の毛管上昇高は, 自然の土堙構造 の下で, 約 30 $50 \mathrm{~cm}$ であるから ${ }^{2)}$ ，地下水位が約 $1 \mathrm{~m}$ 以深にあるときは, 根群層の水分は, 降雨の分 布に応じて，カンガイによって補給しなければ，作 物の経済的生産量を確保できるような水分に保たせ ることができない.

砂丘地土壤は，例えば，第 1 表に示す水分特性を 有している . 固場容水量は約 $7 \%$ であり, 地下水 位の低い場所においては，重力に抗して保持される 水分量は比較的少ない. 根群層内の有効水分量（植
第 1 表 砂丘地土堙の水分特性

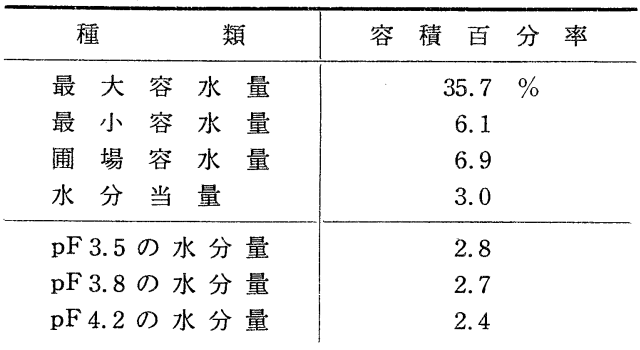

物の生育に有効な水）は，固場容水量から永久しお れ点までとされているが，土堙水分が永久しおれ点 までになると，植物の生長に大きな障害になるので, 実際には，永久しおれ点より上の水分状態でカンガ イをすることが必要である，その下限水分について は，根群層内の水分コウ配を考慮して，層内の平均 水分量が，煵場容水量と永久しおれ点との中間，あ るいは水分当量, または $\mathrm{pF}^{3)} 3.0$ に相当する水分 量になったときにカンガイをすべきであるとされて いる. 砂丘砂では約 $3 \sim 5 \%$ の水分量となる. した がって, 有効水分量は, \{(粗場容水量) 一(永久しお れ点) $\} \times$ (根群層の深さ) で求められ，18 27 (mm) であるが，経済的生産を確保するためには，1回の カンガイ水量は, \{(畕場容水量) - (カンガイ下限水 分) $\} \times$ (根群層の深さ) で求められ, 下限水分を $3 \%$ とすれば，16〜24(mm) となる. したがって，下限 水分に達したときに16〜24m moカン水をすれば, 深部浸透による損失がなく合理的である. カンガイ の間断日数は土壌面からの蒸発量と植物体からの蒸 散量によって決定される. この蒸発散量は作物の種 類および気象条件によって異なるが，普通作物およ び園芸作物では，夏作のピーク時に約 $7 \mathrm{~mm} /$ 日であ

* 鳥取大学農学部

1）遠山正瑛・長 智男（1956）：砂丘地農業と畑地灌溉法. 農業及園芸，31，8～9.

2）長 智男他 (1968)：木場地盤の含水率と機械の走行に関する研究(植生と土堙水分の挙動に関する研究). 九州大学農学部土質理工学研究報告, 12 号.

3）土壌水分吸引力の強さを表示する単位で，土壌粒子が水分を引きつけている力を水柱の高さ $(\mathrm{cm})$ で表 わし，それを常用対数值にしたもの. 


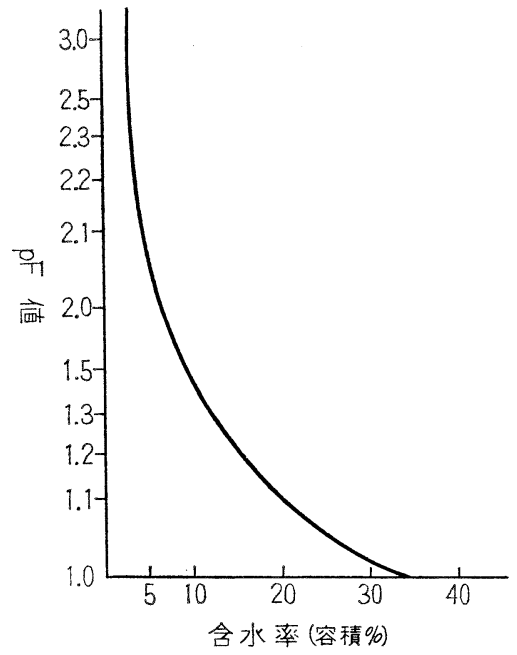

第 1 図 $\mathrm{pF} \sim$ 水分曲線

る. したがって, 根群層内の土袞水分が固場容水量 から下限水分まで低下するのに要する時間は約 3 日 であり, 夏期晴天下では，この間隔でカンガイを行 なえばよいということになる.

砂丘地におけるカンガイの必要性は $\mathrm{pF}$ 水分曲 線（第1図）によっても明らかである2．，砂におい ては，ある水分以下になると，水分のわずかな減少 に対して $\mathrm{pF}$ 值が急に上昇するので，カンガイの管 理が重要な意義をもつ. 砂丘地においては気象条件 の変化がはげしい，外国の乾燥地においては，比較 的多くの実測資料があり，蒸発散量と気象要素との 関係も比較的簡単な関係にあるが，日本における実 測資料は乏しく, 気象要素との関係，土壌の物理性 の変化, カンガイの仕方による影響は今後の研究に またねばならない。

\section{III カンガイ方式の発展}

砂丘地に打いては，昔から苛酷な労働の桶カンガ イが行なわれていた. 昭和 $24 \sim 25$ 年の調査による と4)，鳥取県湖山および北条において，10 a 当たり $7 \sim 10 \mathrm{~m}^{3}$, すなわち, $7 \sim 10 \mathrm{~mm}$ に相当するカンガ イを毎日行なっており，労衝上の制限から 40 a 以上 の作付は不可能であった．他所におけるカンガイ事
例およびその組織は，例え動力を使っていたにして も，いずれも小型の動力による小口径の打込井より の揚水を鉄管または木樋によって導水し，ホースに よる散水か，または地表法によって浸潤させる小規 模組織のものであった.

一般に，現在用いられているカンガイ方式として は，地表カンガイ法と散水カンガイ法が代表的なも のである．砂丘地では浸透能がきわめて大きいため に，地表カンガイ法（地表面に水を流して配水する カンガイ）は深部浸透損失水量が多く，浸透能の抑 制や水路配置に制限が多いので，現在ではすべて散 水カンガイ法を用いている.これは，水に圧力をか けてノズルから噴射させ，カンガイする方法であり， この代表的なものがスプリンクラー法である.

昭和 28 年, 鳥取大学砂丘試験地（現在は砂丘研 究施設）にロータリスプリンクラーカンガイ組織が 設置され，カンガイ事業への適用に関する検討が進 められた なく日本の畑地の諸条件によく適合し，今日までわ ずか 10 数年の間に，全国の地区に適用されるに至 った．スプリンクラーカンガイ計画実施地区の増加 とともに，資材や器材の開発も盛んになり，また， 農業用管水路の技術も発展した. 散水器も中圧型か ら大型，小型および低角度型と種々開発され，現在 では，耕地条件打よび営農条件に対して，種々の方 式が適用されるようになっている6

近年, 労㗢生産力および土地生産力の向上を目標 として, 固場整備事業が進められ, 戋場の整地と整 形，農道と排水路の配置とともに，カンガイ組織も 大型区画に適した方式に変えられつつある. 従来の 中圧型スプリンクラー(ノズル圧, $1.5 \sim 3.5 \mathrm{~kg} / \mathrm{cm}^{2}$ ) を用いた線移動方式（第 2 図）に代って，大型散水 器 $\left(3.5 \sim 7 \mathrm{~kg} / \mathrm{cm}^{2}\right)$ を用いた点移動方式（第 3 図） か，あるいは安価な資材を使った一作期間地上ライ ン定置方式が考慮されている．線移動方式は，固定 配管された幹線と, 可搬式とした支線によって, 順 次カンガイする方法であり, 中圧型スプリンクラー を用いるため, 散水半径も約 $15 \mathrm{~m}$ 程度で, 移動に も労力がかかる. 点移動方式は, 大型散水器を用い

4）鳥居菅生・長 智男 (1951)：砂丘地の灌溉に関する研究. 農業土木研究, 19, 1 .

5) 鳥居菅生・長 智男他 (1954)：鳥取大学浜坂試験地の灌溉施設, 特に回転撒水器による灌水設備につい て. 砂丘研究, 1, 1 .

6）長 智男 (1967)：砂丘地に打ける灌がい法の発展. 砂丘研究， 13, 2. 


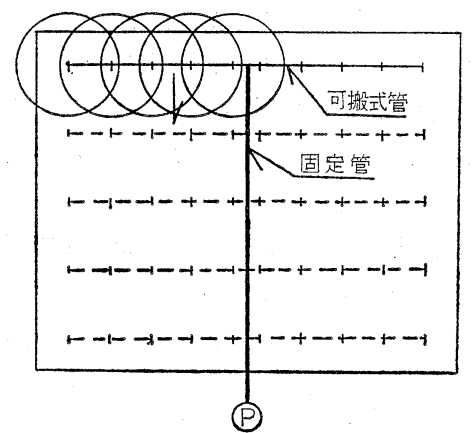

第2図線移動方式の模式図

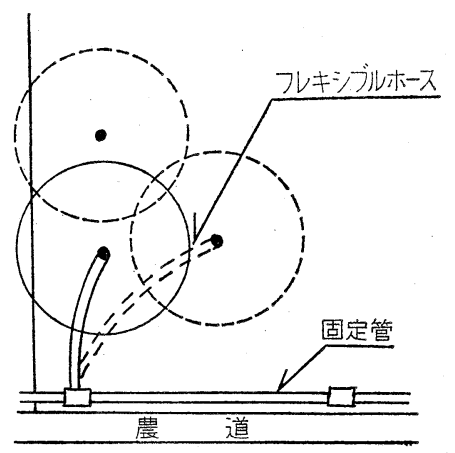

第 3 図点移動方式の模式図

るので, 散水半径も約 $25 \mathrm{~m}$ と大きく, 可撓性耐圧 ホースを用いている．固場整備によって区画の一辺 が長くなり，スプリンクラーラインが長すぎると， 移動に労力がかかり，圧力差を小さくするためには， 管の口径を大きくしなければならず，また，大型機 械の走行に対して固区内に突出した固定施設を設け ないで，すべて道路に沿った管から水を使用するの に適した方法である. 一作期間地上ライン定置方式 は, 水稲の畑作や砂丘地などでカンガイ間断日数の 短かい場合に，ラインを移動させず，一作期間中は 地上ライン定置をさせて拉く方式で, 高圧型スプリ ンクラーを使用している.

砂丘地のカンガイでは, 作物の根群層の有効水分 量が小さいために，高い散水分布の均等性が要求さ れる. 1 個のスプリンクラーの散水分布は，適正圧 力の下で, 中央山形の円錐分布を示す. 分布型は水 圧，ノズルの口径や型および風速や風向によって異 なる. 散水器を適当な距離と間隔に配置し, その散
布型を合成して，できるだけ均等にすることが必要 である. すなわち, 配水と散水効率に関する検討が 一層重要である.

\section{IV 砂丘地の水資源}

砂丘地カンガイの水源として，まず，もっとも近 い地下水の利用が考えられる. 砂丘地の地形は, 堆 砂層の下にある洪積層の原形とは場所によって異な るので, 帯水層の位置, 地下水位の変動および地下 水の流速と流動方向についての調査が必要である. 砂丘地では，浸透能が大きいから，地表流出を生じ ない. 自然の裸地に打ける降雨の地下水補給率は 85 ～90\% を示し，蒸発量は $15 １ 0 \%$ にすぎない，砂 面蒸発量は, 夏期でも平均 $0.8 \mathrm{~mm} /$ 日程度であり, これは表面に気乾砂層が形成され，毛管上昇が断た れるからである.しかし，植生があれば，補給率は 大きく減じ, 畑作物栽培下では降雨量 $55 \%$ に低下 する. 夏作期間では, 蒸発散量は年間の $3 / 4$ を占め, 地下水補給率は $50 \%$ 位になる7)。これらの結果は, 年間の自然降水量の下でのライシメー夕実験結果の 例である.

このように，砂丘の利用状態が水収支に影響を及 ぼすので，裸地を農耕地化したり，林地を開暨する などにあたっては，水収支の推定がなし得るような 基礎的調査が必要である. 開墾によって，砂丘地全 体の水収支のバランスの変化が生じ, 地下水位が上 昇したために，従来低地に栽培された果樹が，根の 浸水によって植栽しなおした例があり，また，季節 的に地下水位の上昇により, 根群層が浅くなったり, 病害が発生したりするため, 排水を必要とする地区 当多い。

地下水をカンガイ用水のための水資源とする地区 は，比較的小規模な地区であるが，用水源を河川や ダムに依存する大規模地区も，一方では排水すると いう例が多い.これは, 耕地としての利用状況の变 化に対する水収支の推定打よびカンガイ排水の実施 後の変化の推定が難かしかったり, 自信が得られな いためである. 砂丘地の地下水利用計画の実施にあ たっては，水文調查を詳しく実施することが望まし く，また，基本的研究が必要である.

7）長 智男（1965）：砂地におけるオーチャードの消費水量について. 昭和40年度農業土木学会大会講演集. 


\section{Vあとがき}

高度な農業的利用にあたって，砂丘地ではカンガ 傠備は欠くことのできない条件である.この場合, 砂丘地の自然条件を生かした栽培法と機械化体系を
確立することが必要であるが, カンガイ施設の多目 的利用（水分補給, 液肥散布, 病虫害防除, 防霜, 飛砂防止など）を考虑すれば，きわめて興味ある農 業を展開させることができょう.

\section{IRRIGATION SYSTEM IN SAND DUNE AREAS AND WATER RESOURCES}

\section{Tosio CHO*, Tomohisa YANO*}

The sea-shore sand dune in Japan covers an area of about 230, 000 ha. In the sand dune areas in humid regions, root zone depths are so shallow and the amount of soil moisture available for plant growth is so little that the interval of supplementary irrigation is short and water depth per irrigation is comparatively small. Of irrigation methods, the splinkler methods was first introduced in 1953 and various sprinkler methods were developed as to the conditions of arable land and plant. In sand dune area, there is no surface runoff and the amount of average evaporation from soil is so little and therefore, nearly all the precipitation is recharged as groundwater. The water balance is largely varied with the existence of plant, the state of its growth and irrigation system.

\section{海岸砂丘地の土地利用}

\section{一主として農業的土地利用について——}

\section{岩 永 実**.今 并 鐳 蔵**}

日本全国に約 24 万ha の海岸砂丘地があるといわ れており，その分布も海岸を有するほとんどの道府 県にまたがっていて，土地利用の状態も極めて多様 である.かつて昭和 28 年に行われた調查によれば1), 砂丘地全体からみると耕地としての利用は約 $34 \%$ にすぎず，あとは防風林などを含む林地が約 $40 \%$ ， 未利用地として残されている土地が約 $26 \%$ を占め ていた．それから 10 数年を経た今日ではもちろん その土地利用の状態はかなり変っており, その後の 全国的な統計がないので数值をもってその変化を示 すことはできないけれども，各地でかんがい施設の 導入が行われて農業的土地利用が進み, 都市近郊の 砂丘地では宅地化や工業用地化などが急速に進んで いる.いずれにしてもいまや砂丘地はその自然のま

Geographical Review of Japan 42-3 1969.

** 鳥取大学

1）昭和 28 年 7 月, 農林省大臣官房総合開発課調查.
まの姿でとどまっているところは非常に少くなりつ つあって, 自然保護の立場から一部の特定地区では 砂丘の維持, 保護の対策が必要となっている実状で ある.このように急激に変化しつつある砂丘地の土 地利用は，大きく分けて農業的利用と非農業的利用 の 2 つ分けられる. そのうち目ざましく発展しつ つある非農業的利用は主として都市近郊砂丘地にみ られ，農業的利用は農村部の砂丘地に限られつつあ る. ここでは後者の農業的土地利用について，鳥取 県下の砂丘地を例にとって自然的, 社会的諸条件の 両側面から考察し, 問題点を明らかにして, 今後の 砂丘地の農業的土地利用のあり方なり方向を見出し たい.

* Faculty of Agriculture, Tottori Univ. 
第 1 表 海岸砂丘地土壌の理化学性

\begin{tabular}{|c|c|c|c|c|c|c|c|c|c|c|c|}
\hline 性 状 & $\begin{array}{c}\text { 粗 } \quad \text { 砂 } \\
\\
\begin{array}{c}\mathrm{mm} \\
2 \sim 0.25\end{array}\end{array}$ & $\begin{array}{lr}\text { 細 } & \text { 砂 } \\
& \mathrm{mm} \\
& \mathrm{mm} \\
0.25 \sim 0.05\end{array}$ & $\mid \begin{array}{lr}\text { 微 } & \text { 砂 } \\
& \mathrm{mm} \\
0.05 \sim 0.01\end{array}$ & $\begin{array}{cc}\text { 粘 } & \text { 土 } \\
& \mathrm{mm} \\
0.01 & \text { 以下 }\end{array}$ & 性 & $\begin{array}{l}\text { 孔 } \\
\text { 隚 } \\
\text { 率\% } \\
\end{array}$ & $\begin{array}{l}\text { 全 } \\
\text { 窒 } \\
\text { 素\% }\end{array}$ & $\begin{array}{l}\text { 淮 } \\
\text { 植\% } \\
\end{array}$ & $\begin{array}{c}\mathrm{PH} \\
\left(\mathrm{H}_{2} \mathrm{O}\right)\end{array}$ & $\begin{array}{l}\text { 置 } \\
\text { 換 } \\
\text { 容 } \\
\text { 量 }_{\mathrm{me}}\end{array}$ & $\begin{array}{l}\text { 被 } \\
\text { 酸 } \\
\text { 吸 } \\
\text { 你 } \\
\text { 数 }\end{array}$ \\
\hline 鳥取未耕地 & 83.7 & 15.3 & 0.2 & 0.6 & 砂土 & 56.4 & 0.049 & 0.14 & 6.8 & 1.60 & 61.6 \\
\hline 鳥取耕地 A & 88.6 & 8.4 & 0.4 & 2.4 & " & 59.8 & 0.170 & 1.02 & 5.9 & 2.40 & 215.0 \\
\hline B & 86.5 & 12.5 & 0.3 & 0.8 & $"$ & 57.1 & 0.080 & 0.29 & 6.6 & 2.10 & 421.0 \\
\hline $\mathrm{C}$ & 80.0 & 11.0 & 1.0 & 8.0 & " & 69.6 & 0.110 & 1.09 & 6.0 & 8.13 & 524.0 \\
\hline 弓浜耕地 A & 74.6 & 19.1 & 0.3 & 6.0 & $" \prime$ & 60.0 & 0.090 & 1.02 & 6.4 & 7.24 & 480.0 \\
\hline$" \prime \quad B$ & 67.6 & 30.2 & 0.5 & 1.7 & " & 60.9 & 0.007 & 1.10 & 6.2 & 7.57 & 676.0 \\
\hline 北 条 耕 地 & 76.5 & 19.5 & 0.1 & 3.9 & " & 58.2 & 0.301 & 1.61 & 5.8 & 5.21 & 192.7 \\
\hline
\end{tabular}

第 2 表砂丘地土壌の特徵と耕地適性

\begin{tabular}{|c|c|c|c|c|c|c|c|c|c|c|}
\hline & 価 & $\begin{array}{l}\text { 表 土 } \\
\text { の厚さ }\end{array}$ & $\begin{array}{l}\text { 有効土 } \\
\text { 層の澡 } \\
\text { 巳 }\end{array}$ & $\begin{array}{l}\text { 表土の } \\
\text { 礫含量 }\end{array}$ & 耕 枟 性 & 土地の乾湿 & 自然肥沃度 & 養分の豊否 & 侵 蝕 & 地 温 \\
\hline & 丘地土袞の特徵 & $\begin{array}{l}\text { 一般に } \\
30 \mathrm{~cm} \\
\text { 内外で } \\
\text { 厚い. }\end{array}$ & $\begin{array}{l}1 \text { m以 } \\
\text { 上で深 } \\
\text { い. }\end{array}$ & な & $\begin{array}{l}\text { 農具を使う } \\
\text { に当っ土 } \\
\text { 堙が反耘し } \\
\text { 難い. }\end{array}$ & 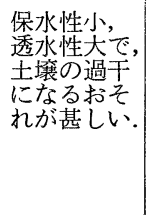 & $\begin{array}{l}\text { 固定力ごく } \\
\text { 小, 保肥力 } \\
\text { も小で, 塩 } \\
\text { 基状態は不 } \\
\text { 良である. }\end{array}$ & 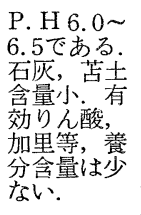 & $\begin{array}{l}\text { 風蝕の } \\
\text { 执それ } \\
\text { が多い. }\end{array}$ & $\begin{array}{l}\text { 日中の } \\
\text { 最高, } \\
\text { 最低地 } \\
\text { 温較差 } \\
\text { が大き } \\
\text { い. }\end{array}$ \\
\hline 耕 & 耕耘の難易 & & 容 易 & 容 易 & 一部問題あり & 容易 & & & & \\
\hline 作 & 地力の発現 & & $\begin{array}{l}\begin{array}{l}\text { 可能性 } \\
\text { あ }\end{array} \\
\end{array}$ & & & & 小 & 小 & & \\
\hline 性 & 侵 蝕 防 止 & & & & & あ り & & & あり & \\
\hline 生 & 根 圏 の 制 限 & な し & な し & な し & & あり り & & & & \\
\hline 育 & 養水分の吸収性 & & & & & 小 & & & & \\
\hline 性 & 同化生産の制限 & & & & & & & & & あり \\
\hline
\end{tabular}

\section{I 耕地としての自然的条件}

砂丘地が農業生産の対象として，どういう自然的 特性をもっているかを考察することは，そこに働き かける生産手段なり，生産方法のあり方を検討する 上に重要である. まず砂丘地の植物生産の場として の土地条件を検討し, 生育のための制約要因を把握 しなければならない，もちろん砂丘地といっても， 地質的, 地形的にいろいろあって, その土地条件も 一概にいうことはできないが，一応鳥取県の主な砂 丘地帯である鳥取, 北条, 弓浜の三地区を例にとっ て，それぞれ土堙の理化学性をみると第 1 表のよう である。

この表でわかるように地区によってかなりの差異 はあるが，いずれの地区も粗砂と細砂で 90〜 98\%を 占め, 粘土の占める割合が非常に少ない。すなわち
粘土はいずれも 8 \%以下で，未耕地になると僅かに $0.6 \%$ という微量を示すにすぎない.この粘土（粘 土鉱物）の量が少ないため，塩基置換容量が非常に 小さく, 平均的な壌土の $1 / 3$ から $1 / 10$ 程度という 值である. そのため養分の吸着力が非常に弱く保持 力にそしいわけで，いわゆる肥沃度が低いといわれ るゆえんもここにある．また腐植も少なく $1 \%$ 程度 で，平均的㙵土の $1 / 5$ 以下である。 その他燐酸吸収 係数も過少であり，直接養分の豊富さを示す全窒素 の含有割合も，地域によってかなりの差はあるが， 平均的壌土に比べて非常に少ない.

以上のような理化学性（本質）の植物生産の場と しての発現形態（現象）をいくつかの生育性要因と して把え，耕地としての適性を検討すると第 2 表の ようである.

ここでみられるように，砂丘地の耕地としての適 
性は，作物の耕作性，生育性 ともにそのままの姿では一般 に低いことは明らかである. その制約要因として主なもの といえば, 土壌の乾燥, 地力 の低位，養分の欠乏，風蝕な どである.この基本的な制約 要因に附随して，地温較差の 大きいことなど派生的な制約 要因も出て打り, 砂丘地の耕 地利用の阻害要因は一般に多 い. 更に害際に耕作した場合 の派生的制約要因として，養

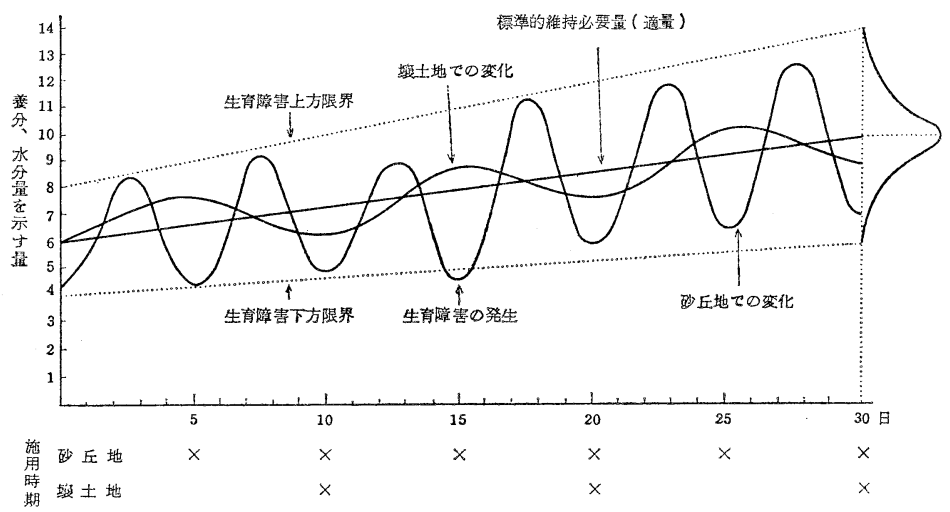

第 1 図施肥および灌水に伴う土壤中の養分および水分の変化に ついての模式図 水分の土壌中に打ける緩衝能

の低いことがあげられる.すなわち第 1 図に示すよ うに砂丘地は保水力や養分の吸着力が低いため, 養 水分の供給事情による影響が単的に表れ易く, 土壤 中において激しい変化を繰り返す。そのため一定必 要養水分の上限, 下限範囲を出やすくて生育障害を おこしやすい，このことが砂丘地での栽培ひていは 農業経営のむずかしさにつながる基本的要因となっ ている.

\section{II 砂防，水利の開発と土地利用}

前述のような自然的特性をもつ砂丘地で作物の栽 培を行うには, 主な阻害要因である養水分の不足を 補うこと, 飛砂を防止して風蝕からまもることの 2 つの課題と取り組まねばならなかった. 砂丘地の土 地利用の発展も, この防風, 防砂と水分を補うため のかんがい方法の開発段階に対応するもので，極め て密接な関係をもっている，そこで鳥取県北条砂丘 地を例にとって，2つの必要な技術的条件のうち， まず水利関係についてみると, 古くから最近のかん がい施設ができるまでは，浜井戸と称する砂丘地の 野井戸から地下水を桶などにより波み上げ，人力に よってかん水するいわゆる桶かんがい（担送かんが い)の方法をとっていた.この方法はかなり労働集 約的な作業になるのと，地下水という自然的制約の ため, 明治中期までの棉作, それ以降の野菜作など の労働集約作物に適応したが，あまりにも制約が大 きく，土地利用を大きく発展させる力とはなり得な かった．その上土地と結びついた浜井戸の個別性と 地下水という自然的規制は，零細にしてかつ分散的
な土地所有とも密接に結びつくものであった. こう した浜井戸によるかんがい、時代には, 砂丘地の中心 作目は面積的には無かん水作物にならざるを得なか ったわけで，明治中期以降のその商品性と結びつい た桑作（養蛋業）や，昭和の第二次大戦中食糧増産 の名の下に栽培された甘藷などはその代表的なもの であった. 終戦後 1 時小規模の動力（発動機）によ る揚水が各地に普及し, 砂丘地での各作物の生産性 はかなり向上したが，その水源は依然として浜井戸 であったので，かんぶい方式の性格を基本的に変え るものではなかった. その後この北条砂丘では, 昭 和 27 年着工し，10 年余りかかって完工した大規模 な畑かん事業によって，浜井戸による制約から離れ， 河川に水源を求めた撒水かんがい方式が出現し, 全 面的なかん水集約作物の栽培が可能になった. この ことは浜井戸に打ける土地そのものと水利の一体関 係を分離し，両者の制約関係を緩和することによっ て, 個别的, 分散的にして零細な土地利用から, 集 団的, 集約的にして大規模な土地利用への可能性を 開くことを意味している.

一方風蝕に関しては, 飛砂防止, 砂丘地固定のた め, いろいろな防風林や防風垣が設けられたが，こ れは土地利用の発展段階に対応しており, 現実の土 地利用より若干先行して行われた. したがってこの ような飛砂を固定する事業は, 土地利用の事情に応 じて，外側砂丘帯や丘陵地を中心に行われたが，そ のための投資はかなりの額の先行投資となったので， 明治以前は新田開発を行った豪農（のちの寄生的地 主）などの手によって行われていたようであるが， 
明治以後においては，直接，間接国や県の助成によ って部落（共同体）が行う場合が多かった．その意 味もあって, また防風林の地域性からその土地所有 の状態がどうであれ，防風林そのものは地域共同体 の規制下にあったとみてよいだろう。この防風林な どの地上物件の共同体的性格と土地所有の個別性の 矛盾は，零細な土地所有で権利関係の入り乱れてい るところに現われやすく，砂防のための緑地化の制 約となり，土地利用の停滞にも及んでいたと考えら れる.

\section{III 商品作物の導入己栽培技術の変革}

砂丘地の農業的土地利用は，かんがい技術の発展 段階に対応するものであったが，より基本的には社 会経済の発展段階に対応して発展するものであった。 明治以前の近世資本主義の発生の初期, すなわち未 だ自給自足的性格の強かった経済下では，砂丘地は 水田開発以外には一部の棉作を除いてあまり利用さ れなかったが，その自然条件に適応（無かん水）す る商品作物が現れるや，その土地利用は飛躍的に発 展していった。つまり桑作がそれで明治中期まで放 置されていた砂地が，大正時代から昭和の初めにか けて, 海岸線や丘陵地の防風林を残して殆んど桑園 化してしまった (第 2 図参照)。桑作が養虫業とい う労働集約的ではあるが, 極めて商品生産の性格の 強いことから, 当時の経済発展に対応し, しかも殆 んど無かん水で生育したため浜井戸かんがいの制約 がなかったことなどが桑作の伸びた大きな要因であ った. 一方浜井戸利用によるかん水作物としては, 明治中期以後ではやさい作が主なもので, 一般に作 付も零細であり, 桑作に比して代表的な商品作物と はなり得なかった. 結局この時期の浜井戸は, 商品 生産の生産手段としては極めて限定された役割しか

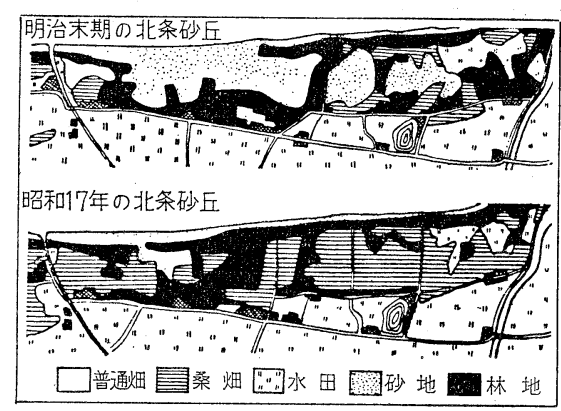

第 2 図北条砂丘の土地利用の変化

果さなかったということができよう.

前述のように河川に水源を求めた撒水かんがいの 施設が導入されるに及んで, 作付作物の種類の制約 が大幅に改善され，如何なる作物もほとんど栽培可 能になったわけであるが, 問題は最近の高度経済成 長下に対応して収益性の高い, 経営的にも容易に導 入し得る商品作物の選択ということにあった. 高度 経済成長下での, しかも零細な経営規模における経 営体の下での収益性の高い作物というと, 普通の壤 土という条件でもなかなか見出すことが容易でない のに, 土袞条件の不安定な砂丘地では尚更むずかし い課題である.この北条砂丘の場合には，一応これ らの条件に適応したものとして葉たばこが導入され た、葉たばこの栽培は, 畑かん施設導入後の昭和 35 年以降急速に伸びた (第 3 表). 昭和 40 年以降も更 に作付がふえているものと想定され，現在砂丘地作 物の中心的存在となっている.これは技術的には撒 水かんがい施設でしかも水量的に制約の少ない河川 を水源とするため, 大面積の集団栽培を可能にした こと, 経済的には商品化が容易で, 価格も安定し, かつ作柄も安定してきたので結局相対的に高い所得 が得られるようになったことなどに基いている.

第 3 表 主な作物の作付状況と家畜の飼養状況

\begin{tabular}{|c|c|c|c|c|c|c|c|c|c|c|c|c|c|}
\hline \multirow{2}{*}{\multicolumn{3}{|c|}{ 区 }} & \multirow{2}{*}{ 分 } & \multicolumn{3}{|c|}{ 主な畑地作付面積（ha） } & \multicolumn{3}{|c|}{ ぶどう面積（ha） } & \multicolumn{2}{|c|}{ 家 } & \multicolumn{2}{|c|}{ 畜（頭, 羽) } \\
\hline & & & & 甘 藷 & 野菜類 & 葉たばこ & 成 園 & 末成園 & 計 & 乳用牛 & 肉用牛 & 豚 & にわとり \\
\hline \multirow{3}{*}{ 北 } & \multirow{3}{*}{ 条 } & \multirow{3}{*}{ 町 } & 35 年 & 72 & 74 & 37 & 62 & 41 & 103 & 62 & 492 & 417 & 10,102 \\
\hline & & & 40 年 & 28 & 202 & 123 & 61 & 15 & 76 & 55 & 175 & 2,892 & 5,262 \\
\hline & & & 增 減 & $\triangle 44$ & 1.28 & 86 & $\triangle 1$ & $\triangle 26$ & $\triangle 27$ & $\triangle 7$ & $\triangle 317$ & 2,475 & $\triangle 4,840$ \\
\hline \multirow{3}{*}{\multicolumn{3}{|c|}{ 中 北 条 地 区 }} & 35 年 & 22 & 29 & 21 & 45 & 30 & 75 & 3 & 130 & 49 & 4,581 \\
\hline & & & 40 年 & 4 & 59 & 75 & 45 & 9 & 54 & 8 & 22 & 164 & 2,698 \\
\hline & & & 增 減 & $\triangle 18$ & 30 & 54 & 0 & $\triangle 21$ & $\triangle 21$ & 5 & $\triangle 108$ & 115 & $\triangle 1,883$ \\
\hline
\end{tabular}


また畑かん施設の導入によって葉たばこばかりで なく,砂丘地の土地利用を多椂化し，長芋やにんじん， ごぼうなどの根菜類の栽培もより盛んとなり，施設 園芸なども行われるようになった. 更に施肥法など 栽培技術においても, 液肥の施用を一般化し, 砂丘地 の養分不足を比較的容易に解決する糸口をつくった. こうして何時でもかん水できるということが適期作 業を容易にし栽培技術体系をも変革するもので，結 局作柄の安定化，生産性の向上につながっている.

\section{IV 土地利用の農業経営的条件}

農業的土地利用は，通常個別の農業経営を通して 行われるものであるから，経営体自身の性格なり， 経営体のおかれている社会経済的諸条件を検討する ことも必要となる. まず土地利用の担い手である砂 丘地農家の経営条件をみると, 砂丘地そのものの経 営面積の零細なことがあげられる(第 4 表).すなお ち1戸当りの砂丘地耕作面積は 40a〜 50a で，いず れの農家も水田二稲作と結びついており，砂丘地は 経営的に補完的な役割しか果していない農家が多い. したがって土地利用の経営的意義は，農家によって 非常にまちまちである.しかし農家によって砂丘地 の経営的位置づけがどうであろうと，かんがい施設 投資の負担が土地改良費などの名目でかかってきて おり，その負担をカバーするためにも商品作物生産 の場とせざるを得なくなっており，現今のような高 度経済成長下では尚更である. 砂丘地でも経営の零 細性と商品生産の矛盾が大きく露呈されている.

またかんがい施設と耕地条件の対応関係が問題に なってきた.すなわちかんがい施設の水利方法に合 せて，耕地の区劃を整理することが必要となり，そ
第 4 表 1 戸当り砂丘地面積

(昭35. 北条町役場調)

\begin{tabular}{|c|c|c|c|c|c|c|}
\hline \multicolumn{2}{|c|}{ 地区, 部落 } & 普通畑 & 桑 園 & 果樹園 & その他 & 計 \\
\hline \multirow{3}{*}{$\begin{array}{l}\text { 中 } \\
\text { 北 } \\
\text { 条 }\end{array}$} & 東新田場 & $15^{\mathrm{a}}$ & $4^{a}$ & $15^{\mathrm{a}}$ & $7^{a}$ & $41^{\mathrm{a}}$ \\
\hline & 坂 & 14 & 12 & 18 & 2 & 46 \\
\hline & 国 坂 浜 & 15 & 12 & 20 & 4 & 51 \\
\hline \multirow{3}{*}{$\begin{array}{c}\text { 下 } \\
\text { 北 } \\
\text { 桑 }\end{array}$} & 田井 & 17 & 19 & 6 & - & 42 \\
\hline & 弓 原 浜 & 20 & 20 & 6 & 1 & 47 \\
\hline & 神 & 20 & 27 & 4 & - & 51 \\
\hline \multicolumn{2}{|c|}{ 砂丘地帯平均 } & 15 & 14 & 9 & 1 & 39 \\
\hline
\end{tabular}

のため，交換分合，樹園地の移動のための樹木類の 補償など土地所有と耕作権の調整が必要となってき た. 更に経営者自身の技術的問題としては, 砂丘地 はすべての自然的生育要因の変動が大きいので, 普 通の壌土地帯の農業よりも管理作業にムラのない丁 寧さが必要とされており, 砂丘地農家にはそのよう な厳格な管理のできることが要求されている.

\section{$\mathrm{V}$ むず}

以上考察したように砂丘地での農業的土地利用は， 次のような要件なり事情がととのうことによって発 展するものと考えられる. 1. 水利, 砂防を中心と した土地条件の改善とそれに対応する固場の整備,

2. 新らしいかんがい栽培技術体系の開発と集約的 商品作物の導入, 3 . 周到な栽培管理のできる農業 者の存在, 4. 都市近郊のように地価（地代）の高 騰しない地域であること．以上のような諸条件に欠 ける場合は，農業的土地利用は停滞するであろうし， 立地のいかんによっては工場敷地などの非農業的土 地利用の大いな発展が期待されている.

\section{ON THE LAND UTILIZATION IN COASTAL SAND DUNE AREAS}

\section{Minoru IWANAGA and Raizo IMAI*}

This paper dealt with the result of consideration on some factors and the actual conditions of the land utilization for the agriculture in coastal sand dune areas. The authors could make it clear that the development of land utilization are affected by the following factors :

1) The improvement on the cultivable conditions of land by the irrigation and the sandbank fixing with the preparation of field. 2) The development on the system of new culti-

Geographical Review of Japan 42-3 1969. * Tottori Univ. 
vable technique by the irrigation and the introduction of intensive crops for the farming in the sandy soils. 3) The being of the farmers to be managed the farming circumspectly.

4) The adaptations to the agricultural production in preparation for rising the price of land.

\section{砂丘地利用の経済的問題}

\section{坂 本 英 夫*}

砂丘地は水に乏しい特有の景観をもっているため に，景観を重視する地理学界では，以前から砂丘地 を研究する人が多い，ところが，ある程度砂丘地の 研究を進めて, 一応の結論 を出すと，それらの大部分 は, 砂丘地の研究から離れ てしまう傾向がある。その 理由は研究者の資質にも依 るところがあろうが, 砂丘 地のもつ性格にも由来する ことが考えられる. 海岸砂 丘地は, 景観の上では大い に興味をひくフィールドで あるが，経済活動は非常に 弱く, 深く追求しようとす ると, 人文現象は経済的停 滞の暗いよどみにおちこん でしまい,どうしようもな くなってしまう. 砂丘その ものの地学的特性の研究は, 次々と問題が展開されてき た.これに対して, 砂丘地 の開発政策, とくに農業の 高度利用とか, 多角的な産 業開発などについての施策 は，遅々として進まなかっ たこともあって, その研究 の立ち遅れが目立っている. 全国的に，海岸砂丘地の 利用状況がどういう具合に なっているかを示す資料は ほとんど存在しない.「海 岸砂地地帯農業振與臨時措
第 1 表 海岸砂丘地利用状況（昭和 27 年 単位：町）

\begin{tabular}{|c|c|c|c|c|c|c|c|}
\hline & \multirow{2}{*}{ 全面積 } & \multirow{2}{*}{ 不毛地 } & \multirow{2}{*}{ 林 地 } & \multirow{2}{*}{ 耕 地 } & \multicolumn{2}{|c|}{ 耕 地 内 訳 } & \multirow{2}{*}{$\begin{array}{c}\text { 耕地率 } \\
\%\end{array}$} \\
\hline & & & & & 畑 & 樹園地 & \\
\hline 青 森 & 66,467 & 20,339 & 40,030 & 6,098 & 5,921 & 177 & 9.2 \\
\hline 新 潟 & 14,613 & 3,296 & 5,884 & 5,433 & 4,832 & 601 & 37.2 \\
\hline 北海道 & 13,657 & 9,242 & 2,402 & 2,013 & 2,006 & 7 & 14.7 \\
\hline 茨 城 & 11,841 & 1,835 & 6,802 & 3,204 & 3,123 & 81 & 27.0 \\
\hline 石 川 & 11,407 & 2,204 & 6,963 & 2,240 & 1,942 & 298 & 20.0 \\
\hline 静 岡 & 9,850 & 4,745 & 1,852 & 3,253 & 2,985 & 268 & 33.0 \\
\hline 宮 城 & 7,287 & 4,445 & 1,839 & 1,003 & 958 & 45 & 13.8 \\
\hline 山 形 & 7,264 & 1,368 & 3,096 & 2,800 & 2,537 & 263 & 38.6 \\
\hline 鳥 取 & 6,965 & 1,906 & 1,202 & 3,857 & 3,082 & 775 & 55.3 \\
\hline 秋 田 & 6,731 & 2,543 & 3,214 & 974 & 583 & 391 & 14.5 \\
\hline 千 葉 & 6,191 & 2,120 & 896 & 3,175 & 3,167 & 8 & 51.3 \\
\hline 鹿児島 & 5,160 & 1,515 & 2,976 & 669 & 662 & 7 & 13.0 \\
\hline 宮 崎 & 4,607 & 1,287 & 1,898 & 1,422 & 1,373 & 49 & 30.9 \\
\hline 島 根 & 3,473 & 1,179 & 1,028 & 1,507 & 1,090 & 417 & 43.5 \\
\hline 福 岡 & 3,373 & 597 & 2,075 & 801 & 758 & 43 & 23.8 \\
\hline 愛 知 & 2,766 & 943 & 851 & 972 & 942 & 30 & 35.0 \\
\hline 和歌山 & 2,633 & 610 & 1,085 & 948 & 885 & 63 & 36.0 \\
\hline 山 口 & 1,944 & 406 & 637 & 901 & 655 & 246 & 46.3 \\
\hline 高 知 & 1,915 & 613 & 262 & 1,040 & 940 & 100 & 54.5 \\
\hline 福 井 & 1,680 & 558 & 693 & 429 & 291 & 138 & 25.5 \\
\hline 三 重 & 1,311 & 356 & 212 & 743 & 615 & 128 & 56.7 \\
\hline 愛 媛 & 1,242 & 61 & 444 & 737 & 676 & 61 & 59.2 \\
\hline 京 都 & 1,127 & 450 & 297 & 380 & 292 & 88 & 34.7 \\
\hline 大 分 & 1,046 & 242 & 449 & 355 & 245 & 110 & 33.9 \\
\hline 福 島 & 998 & 418 & 365 & 215 & 196 & 19 & 21.6 \\
\hline 岩 手 & 980 & 548 & 274 & 158 & 153 & 5 & 16.1 \\
\hline 神奈川 & 971 & 244 & 220 & 507 & 506 & 1 & 52.2 \\
\hline 徳＼cjkstart島 & 810 & 160 & 229 & 421 & 415 & 6 & 52.0 \\
\hline 東 京 & 664 & 247 & - & 417 & 417 & - & 62.9 \\
\hline 富 山 & 469 & 114 & 45 & 310 & 300 & 10 & 66.0 \\
\hline 兵 庫 & 137 & 71 & 47 & 19 & 19 & - & 13.9 \\
\hline 香 川 & 129 & 24 & 13 & 82 & 80 & 2 & 63.5 \\
\hline 合 計 & 200,049 & 64,686 & 88,280 & 47,083 & 42,646 & 4,437 & 23.5 \\
\hline
\end{tabular}

* 山形大学

置法」が昭和 28 年に制定されたが，その為に農林 省が各都道府県に該当地域の資料を提出させたもの が，唯一のものといってよい．これを集計整理した

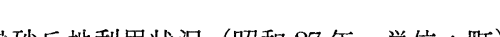


わのが，第 1 表ならびに第 2 表である. 海岸砂地地 帯の指定基準は，潮風又は潮流によって堆積された 砂土に打打われている土地の 100 町歩以上が集団的 に連続する地域，と定められている。したがって， 箃密な意味での海岸砂丘のみならず, 浜堤, 砂嘴, 砂洲などの土地も含まれている．この資料には，水 田面積も全国で約 4 万町歩あるが，砂丘地における 水田の基準があいまいであるために，水田面積は削 除した（本資料は補助金を得るために作製されたこ とに留意したい)．水田の約 4 万町歩を除くと，わ が国の海岸砂地地帯は 20 万町歩であり，そのうち， 不毛地（裸地，草地，漁干場を含み，次のものを除 く. 宅地，工業用地，交通用地，公園，軍事基地， 内陸水路，塩田，鉱泉地，雑用地等） が 64,686 町 歩 (32. $4 \%$ )，林地が 88, 280 町歩 ( $44.1 \%)$ ，耕地が 47,083 町歩（23.5\%）となっている.

耕地率が低い砂丘地は，北海道を含めて，秋田， 宮城県以北の地域と，鹿児島県にある。ただし，北 海道でも札幌に近い石狩湾沿岸地区 $(1,883$ 町歩 $)$ は例外的に高い耕地率（35\%）を示している。ここ では蔬菜園芸が盛んで，スイカ・ウリさえも栽培さ れている. 大規模な砂丘地は一般に耕地率が低い。 500 町歩以上の砂丘地で耕地率が $50 \%$ 以上のものは, 第 2 表の如く，全国 6 ヶ所にすぎない．これらは都 市の近くに位置しているものか，又は海岸砂丘とい うよりも，隆起性の旧浜堤や砂洲など低平なものに 限られている。

わが国の海岸砂丘の開発記録を整理してみると， 大規模な砂丘固定事業が盛んになりはじめた時期と， 砂丘地を耕地として利用しはじめた時期がずれてい ることがわかる．前者は 1600 年代からで，関ヶ原 役以後の各藩の内治充実策とみられる. 後者のうち, とくに重要なのは海岸砂丘地の開㼟による新田集落 形成である。これがみられるようになるのは 1720

第 2 表 耕地率 $50 \%$ 以上の海岸砂丘地

\begin{tabular}{l|r|r|l}
\hline & 面 積 & 耕 地 & 耕地率 \\
\hline 九十九里浜 & 4,899 & 2,738 & $56 \%$ \\
酒田市南部 & 4,250 & 2,109 & 50 \\
弓r浜 & 3,207 & 2,482 & 78 \\
新潟県西蒲原 & 2,984 & 1,652 & 55 \\
湘南砂丘地 & 971 & 507 & 52 \\
和 歌 山 市 & 911 & 705 & 78
\end{tabular}

面積 500 町歩未満の砂丘地は除く
年代からであり，わが国の台地開懇期と一致してい る. 現在，砂丘地を耕作している集落の起源を大別 すれば，次のいずれかに属する.

(1) 漁業・製塩を業としている漁村

(2) 後背湿地の水田利用に立地し，そこから砂丘 地に耕地を拡張した農村

(3) 新田集落であって，水田率の低い畑作村

（4) 第三次産業的な機能（宿場, 港津，市場など） で立地したが，のち砂丘地も耕作するすのもいる都 市的な集落

砂丘地の村として数が多いのは，(1)と(2)である. (1)は沿岸漁業が衰退しても，その代替として農業発 展に力を入れない，農業はやはり従で，出稼ぎや農 外兼業に従事し，農業へのエネルギー投下には消極 的である. (2)は水田経営に熱心で，砂丘地利用には あまり積極的ではないが，有利な農作物（たとえば かつての桑）があれば利用する．以上の点から見ら れるように, 砂丘地の農業利用の高度化には, 農村 の側においても問題点が存在していることがわかる のであるが，その根底にはやはり砂丘地のもつ農業 生産力の低位性がある. すなわち, 前発表者の今井 氏が述べられた如き，土地生産性の低さが海岸砂丘 地を長い間農業限界地帯としての地位にとどめてい た根本要因である．また，そのことと関連して，投 下された労働力に見合う収益が他の地域より遙かに 低いこと，すなわち労働生産性の低さも見逃せない。 そのほか, 資金の不足, 畑作物価格の不安定と低さ なども, 砂丘地の農業発展を阻害していたことと指 摘されなければならない問題である。これとともに わが国の従来の農政における水田経営者の保護優先 と対照的な畑作経営者への冷遇もとりあげられよう。 海岸砂丘地の高度利用についての研究は，まず農 業的土地利用において推進せしめられてきた。わが 国では，鳥取大学をはじめとする裏日本各地の大学 や県農業試験場の努力によって, 砂丘地の農業発展 のための研究はめざましい成果をあげてきている. その結果, 技術の点においては, 海岸砂丘地の農業 体系が確立されつつあるといえよう。ところが，そ の進んだ技術が，大学農場や農事試験場から農村の 場に移ると，必らずしも所期の効果をあげていない． 部分的に成功しているところはあるが，全域にわた り普及しているとはいえない，海岸砂丘には成因を 異にし，地学的特性を異にするものが含まれている 
が，それらが原因で新しい農業技術の普及を妨げて いるわけではない，それを受入れるべき農村側に経 済的, 社会的問題が存在しているのが大きな理由で あると考えられる. 主な点をとりあげてみると，ま ず第一に, 階層分化が激しく, 多数の兼業農家と少 数の専業農家が混在しているために，農業経済の一 体化・社会化が困難であることがあげられる，たと えば, 農業構造改造事業にしろ, 兼担事業にしろ, 灌溉事業には多くの資本が必要であり，そのため共 同化が条件であるが，そのような複雑な社会的・経 済的構造のある村（部落）では，円滑な共同化は望 めないし，多くの場合失敗している. また適作物と いわれる園芸作物を栽培して，収穫をあげても，流 通組織が弱いところでは，その販路に困ることにな る. 専業農家の比重が低いところほど, 流通組織が 弱く, 中間商人の咙扈を許している. また, 前述の 如く, 畑作物価格が低いために, 農家が新しい農業 投資に対してふみ切れないという事情がある. 以上 の問題点は，どちらがニワトリで，どちらがタマゴ であるにせよ, 海岸砂丘地で農業を発展させるには, それぞれの間の悪循環を断ち切る手段を講じる必要 がある．社会的・経済的措置をとることによって， 砂丘地の農業的発展は可能性を展開してゆく余地を もっている.

近年, 海岸砂丘地における工業の用地とか, 住 宅・リクレーション・その他第三次産業の諸施設の 利用が急激にふえている.土木建設資材としての, 河川砂利・山砂利が払底してきたこともあって, 砂 丘の砂の採掘も盛んになってきている. 新しい砂丘 利用がおこってきたことは注目されなければならな いが，これらの間の調整が計画的になされていない
ため, 無秩序な利用によって砂丘地が荒廃しつつあ り災害を招く危険もある. これと関連して, 砂防林 の拡張と充実も忘れられてはならないことである. 開発と保全は表裏一体のものであり, 両者のバラン スをとってゆく必要がある.

砂丘地を開発し，高度に利用しなければならない という発想は，これを対象として研究するものの誰 もが抱くところである. しかし，広大な未利用地を もつ火山灰地や泥炭地, 重粘土地についても, 砂丘 地と同様に開発の必要性は高い筈である. 経済の論 理から見れば，投資効果の大きいところから，開発 すべきであり，同一投資額を他のところに投入した とき，そちらの効果の方が，砂丘地よりも高ければ 砂丘地の開発は，国民経済全体から見て，あまりプ ラスにならぬおそれがある. 砂丘地が開発されるた めには，その特質がもっともよく発揮できる目的の ために利用されなければならない，

最後に，特に注意を喚起したいことがある.わが 国に打ける海岸砂丘地の分布を調べてみると，大部 分の砂丘地は, 太平洋ベルト帯をはずれた地域に位 置している. そういう工業化の遅れた地方の中でも, 「平野の僻地」とか，「陸の孤島」とか呼ばれてい るところが多く, 産業振興による経済発展が望まれ ているところの, いわば典型的な後進地域 Underdeveloped area である. 本大会では，同一時間に 二つのシンポジウムをおこなっており，別会場では 「後進地域の地域開発」のシンポジウムが併催され ているが，これは前後させるべきであった．砂丘の 開発は, この「後進地域の地域開発」シンポジウム と関連させて論ずるべきものであり, 自然条件の克 服のみで解決できる問題ではない。

\section{ECONOMIC OBSTACLES FOR THE AGRICULTURAL DEVELOPMENT OF THE SAND DUNE AREAS ALONG JAPANESE COAST}

\section{Hideo SAKAMOTO*}

There are many sand dune areas along Japanese coast. They number 200, 049 hectares, among them the unproductive bare land having $32.4 \%$, the wooded land $44.1 \%$, and the cultivated land $23.5 \%$ (Table). Besides acreage of the table 1 , the paddy field numbers about

\footnotetext{
Geographical Review of Japan 42-3 1969. * Yamagata Univ.
} 
40, 000 hectares.

People have been dwelling on the sand areas, cultivating the land. But the harvest stays poor. It has been continued by many research workers to effort the agricultural development in the sand areas. Technical side of sand farming reached high level in the experiment stations. But many farmers don't take the excellent technics, by reason of social, economic, and administrative deffeciency in themselves and arround them. For examles, farmers who cultivate the sand fields own very small acreage of farm land. They are almost the part time farmers who have no will for the more returns from their farms. The market price of products which are regarded as suitable kinds fluctuates or remain down.

コメント 1

\section{水収支研究の立場から}

\section{市川 正 巳*}

降水が地表に達して最終的に流出する過程におい て，貯留の現象が起こる，すなわち，表面貯留・河 道貯留・土壌水帯および地下水帯の貯留が生ずる. この中で，土壌水帯と地下水帯の貯留変化の速度は 極めて徐々である. 降水が土塞水帯への浸透によっ て流入し，それが中間流出，下層への透過（percolation）および蒸発散によって流出するという1つ の土壤水分循環を形成する. 土塞水帯は地下水帯と 異なり，水分が不飽和状態にあるのが普通なので不 飽和帯ともいわれる. 土袞水分循環は広域の水収支 を考える場合に，その水収支期間を 1 年にとると， 土穓水帯への水分の流入量と流出量が平衡を生じて ゼロとなる量として従来は取り扱われてきた．しか し，10日間とか 1 ヶ，かんがい期間などのように 短期の水収支を算定する場合にはもちろん，砂丘地 のように浸透が著しくほとんど表面流出のない条件 では，不飽和帯の水収支を明らかにしなければ土地 利用の合理化が不可能である。

砂丘地のようにほぼ均質の砂層内に降水が浸透す る型には，広域にわたって面的に浸透するもの，局 部的な場所に限られて浸透するもの，1 地点（数平 方センチなどの小面積）にのみ浸透するものの三つ があるが，ここでは広域にわたって雨水が面的に浸 透する場合について論ずる.

長 智男・矢野友久の「砂丘のカンガイと水資 源」によると，日本の砂丘地では有効根群層が 40
$60 \mathrm{~cm}$ で，毛管上昇高は 40 50 cm であるから, 地 下水位が $1 \mathrm{~m}$ 以深のときは, カンガイによって水分 を補給する必要があることを述べている.

いま，地表から地下水面までの深さを $H ，$ 毛管上 昇高を $h_{m}$ とすると， $\left(H-h_{m}\right)=h$ はカンガイによ って作物に必要な水分の上限すなわち圈場容水量 $\Omega$ まで補給されるべき砂層の厚さとなる，地表に降っ

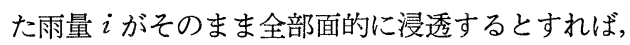
$i=\left(H-h_{m}\right) \Omega$ となる．もし，ある時点における実 際の土壌水分を $S$ とすると, $i=h(\Omega-S)$ となる. ここで，围場容水量を砂丘地で $7 \%$ ，カンガイ下限 水分を $3 \%$ とし, $h=(1000 \mathrm{~mm}-500 \mathrm{~mm})=500 \mathrm{~mm}$ であるとすれば， $i=500 \mathrm{~mm}(0.07-0.03)=20 \mathrm{~mm}$ となり,これが 1 回に補給を要するカンガイ水量と なる. また, 地下水面が深く, 有効根群層の厚さが 大なほど，必要なカンガイ氷量が多くなる．例えば $H$ が $3 \mathrm{~m}$ で, 他の数值が前の例と同じ場合には, $i=100 \mathrm{~mm}$ となり, 1 回のカンガイ用水量が $100 \mathrm{~mm}$ に達することになる．これは，砂丘砂では围場容水 量 $\Omega$ の值が著しく小さいことに起因する.

砂丘地の林地を開拓すると雨水の地下水への補給 率が増大し，地下水面が上昇して果樹の根に浸水し たりするので排水を必要とすることが多いことを指 摘しているが，植生の変化に対応して不飽和帯の水 分貯留の変化すなわち不飽和帯の水収支を明らかに することが，砂丘地の土地利用の合理化をなし得る

* 東京教育大学 
最も重要な点である.「砂丘のカンガイと水資源」 については，特に鳥取砂丘について，地下水面の分 布状態，砂層の厚さの分布，カンガイ期の日雨量の 分布など, 具体的な調查結果を提示して議論を進め て蒷い度かったが，砂丘一般論に傾き過ぎた発表の
ため，十分な討論ができなかったことを遺憾とする ものであるが，今後さらに砂丘地の特定の問題，例 えば砂丘地の水の問題などに限定し，十分な時間を とって討論ができることを希望してコメントとする.

コメント 2

\section{植生の問 題}

\section{吉 野 みど り*}

海岸砂丘の形態や成因は多様であるが，植生の立 場からは，植物の種類・植被率・生活型などにもと ずいて，次の 3 地帯に区分できる．1．不安定帯(移 動砂丘または白色砂丘）砂丘が形成されつつある時 期で, 新しい植物がパイオニアとして入ってゆく. 2. 半安定帯（灰色砂丘と褐色砂丘）砂丘がある程 度植生におおおわれた状態.さまざまな段階がある。

3. 安定帯（固定砂丘）砂丘の移動が全くとまり砂 丘林に打抢われる. 以上の 3 地帯は，砂丘植生の海 岸から内陸への配列であり，また砂丘の発達に伴う 遷移の系列でもある. 各帯の幅は, 砂丘の規模によ り, 数十 $\mathrm{m}$ から数 $\mathrm{km}$ にわたる.

各帯に優占する植物は, 不安定帯ではコーボーム ギ・コーボーシバ・八マグルマ・〔カモジグサ・Ammophila arenaria・Erynyium maritimum] など, 潮 風と飛砂や乾燥に強い多年生植物で, 長い分岐した 地下茎や長大な根をもつ草本が多く，まばらな群落 をつくる.この植生は, 内陸砂丘や湖岸砂丘とも大変 よく似ている. 半安定帯では, 上述の砂丘植物のほ かに，チガヤ・ギョーギシバ・八マゴウ・ビロード テンツキなどが加わり, 砂丘地以外にも生える中生 植物が多くなる.ヨーロッパでは砂丘全体が草本に
おおわれた状態を灰色砂丘，次に人の背丈ほどの灌 木〔ヤナギ類や Hippophaë rhamnoides]におおわ れた状態を褐色砂丘とよぶ. 日本では灌木の時期は はっきりせず，チガヤの高原にクロマツの稚樹が侵 入して次の砂丘林へ移行する. 安定帯は自然林・造 林の別なく，砂丘が固定して，天然更新する森林に おおわれた段階である。棟ではクロマツ林が優勢 で，下生えに二次林や路傍に生える中生植物や帰化 植物が入る. 遷移の極相は, 北西ヨーロッパのナラ= カンバ林, 地中海のマツ林, ミシガン湖岸砂丘のブ ナ=カエデ林である．後者では，極相に達するのに 約 300 年といわれ，日本では，沖積地に極相のシイ 林が成立するまで約 500 年を要している．適当に人 為を加えることによって，この遷移系列を促進する ことができる．防砂垣を作り，砂草を植え，植林す る方法によって，砂丘林の成立を三十年に短縮した 鳥取砂丘の例もある. しかし半安定帯で過放牧を行 ない，または砂丘の草を緑肥に使ったり(北ドイツ)， 八マナスの根を薬用に掘取って（秋田）飛砂や砂丘 の移動を招いた例もある．砂丘の土地利用は，砂丘 地全体の植生のバランスを破らないよう注意が必要 である。

コメント 3

農学の立場加 5

佐 藤 一 郎**

砂丘地農業は，その自然環境特に土壤条件によっ て特徵つけられる. 砂丘土壌は主に粗砂細砂から構
成されており，微砂，粘土分に乏しく，その上動植 物の遺体に由来する腐植成分も極少量にすぎない，

* 資源研究所

** 鳥取大, 砂丘研究所 
従がって容水量, 肥料の吸収量が小さく, 更に肥料 の天然供給量も少なく，いわゆる地力に乏しい土地 である. しかしその反面，非毛管孔炒が多いので， 通気排水がよく，作物の根の生育を促す一面をも。 ている。 また土壤の凝集力, 附着力が小さいので耕 枟作業など容易であり, 特に降雨直後の作業や深耕 を容易にし，更に雑草害も少ないなど好ましい性格 も具有している. 気像環境の点からみると, 地温の 点に特徵があり, 春先の地温上昇の早いことは促成 栽培の好適条件であるが，夏の過高地温は作物の生 理にとって阻害要因となる。な打地温, 気温の日較 差の大きいことは同化物質の転流上好ましい条件で あり，また果実の甘味を増す一因にもなる．更に降 雨にもとずく水蝕の少ない事や降霜害の打それのな いことも好ましい点であるが，他方潮風害や風蝕の 危険性は大きいといえる.

以上のべた砂丘地の自然環境の特性からみて明ら かなように, 砂丘地で農業を行なう場合, その自然 に何等手を加えることなく作物を栽培すれば，飛砂 と乾燥, 肥料欠乏などのため生産が不安定なことは 当然である. しかし砂防林や防風垣で砂や風の害を 防ぎ，灌水施設を設けて適時灌水を行ない，施肥も
砂丘地に合った方法をとり，作物の必要とする時必 要な量の肥料要素を与える. 例えば灌水と同時に施 肥を行なう液肥栽培の如き方法を講ずることによっ て，反って能率的な良質のものを生産することの可 能なことが立証されている.

以上のべたように砂丘地で安定した生産をあげる ためには基盤整備なり施設投資を必要とする.この 場合, それを可能とする農業の確立, 特に作目の選 定なり適作物の導入をはかる事が眼目となる．その 作物は反収が大で, 生産性の高いことは当然要求さ れるが，更に考慮すべきは，それらの作物が砂丘地 の特徵を生かし, 他の土㙵地帯より, より優位に立 つものであるということであって，鳥取県下の砂丘 地で成果を上げている，長芋，ラッキョ，タバコな どはこの例である。これら作物は商品生産の立場か ら主産地形成による良質, 量産, 均一生産が要請さ れ, 北条砂丘, 福部砂丘では 1 品目 150 ha の産地 化が進んでいるが，これも砂丘地が固場整備が容易 であり，その後の機械化営農の点でも好ましい性格 をもっていること，更にこれら投資に対し充分ぺイ する農業を成立せしめることを立証しているといえ る.

コメント 4

\section{$\exists$ ヨッパの砂丘との比較}

\section{浮 田 典 良*}

オランダの北海海岸には，南北 Holland 州の海岸 部を中心に, 北へ延びて西フリージア諸島, 南では Zeeland 州の島々の西端部へと続く，一連の海岸砂 丘が見られる. その幅は広い所では数 $\mathrm{km}$ に及ぶが, 所によっては $100 \mathrm{~m}$ にも満たず，またフリージア諸 島でも島すべてが砂丘ではなく，砂丘は島の外縁部 (大西洋岸）に細長く見られるに過ぎない，ところ で，これらの砂丘はどのように利用されているか. 第一には砂丘は背後の広大な干拓地の保護に役立ち, この自然の堤防の保全の為に, 飛砂防止の植林をは じめ, 砂丘の狭いところでは外側をコンクリートで 固めるなど，万全の意が用いられている. 第二には 農業的利用である. 地下水位の浅い所では, 花卉園 芸, とくに世界的に著名なハーレム—ライデン間
のチューリップ栽培など，集約的な園芸農業が行な われている. 第三には Den Haag 西郊の Scheveningen をはじめとする海岸保養地である. 夏には 国内のみならず，ドイツその他諸外国からも夥しい 保養客が訪れ，かれらの落す金が地域住民の重要な 収入源をなしている. 第四には Den Haag その他 で見られる郊外住宅地としての利用である.

日本の砂丘利用状況と比較すると, 大局的には類 似性が高い，すなわち，日本の土地利用を特色づけ る水田が砂丘には見られず, 一方北西ヨーロッパの 土地利用の大きな特色である牧草地が砂丘には見ら れない. 従って, 砂丘の内側の土地利用はきわめて 異るが，砂丘そのものの利用状況は相対的によく似 ていると言わねばならぬ.

\footnotetext{
京都大学
} 
なお，日本の砂丘の砂は河川ないし海の砂である のに対し，ヨーロッパ北部では洪積世の水河堆積物 と関係する砂，すなわち主としてザーレ氷期のザン ダーないしは fluvioglacial の砂質堆積物から生まれ た内陸砂丘が各地に見られる。これは19 世紀中葉 をで大部分八イデをなし, 主として羊の粗放的放牧 地として共同で利用されていたが，19世紀に私有化
されて植林され，または農地化している．この場合 八イデは必ずしも自然の植生ではなく，八イデ化 (Verheidung) の所産であるという考え方もある. わが国の砂丘利用を見る場合にも，その開拓や植林 以前の状態をすなわち天然のものと考える事は誤り であり，長期間に亘る砂丘利用の変貌を，広い視野 に立って検討する必要があるように思われる。

\section{4）地域開発の問題と砂丘}

地域開発の問題と砂丘

一一茨城県鹿島地域を例にして—

\section{山本 正三*・沢田 清*}

\section{I 地域開発己砂丘}

砂丘地域とは，これを厳密に定義づけることには， 多くの問題があるであろう.しかし，ここでは一般 に考えられているように，いわゆる砂丘が分布する 地域を漠然とさし，砂丘とその周辺の砂質の地域を さすことにしたい.

砂丘地域の開発を大胆に類型化すれば，次のよう になろう．イ）放置された自然のままの状態. それ は植物の被覆は少なく, 飛砂が激しく, 砂丘の移動 現象が顕著で，不安定な状態にある.土地利用とい っても，漁具納屋がおかれたり，比較的安定したと ころで粗放的な農地が例外的に開かれたりする程度 にすぎない，只）次に軍用地の利用．ここでは軍事 体制の強化により，未利用面の広い砂丘地が，演習 場・射撃場また飛行場などに強制的に利用される。 しかし，この利用のための交通整備や平坦化の基盤 整備，また砂丘地の固定化が，やがて他の利用面へ 有利に働くことになろう，八）固定化による農業へ の土地利用. この初歩的段階では天水依存による自 給的農業で, 漁業を兼抆ることが多く, 魚肥が農業 にある程度役立てられている.ニ）固定化とともに 灌溉設備による商品作物の導入, 砂丘地のもつ高燥 性・輻射熱の高温性などが生かされらっきょ・たば こ・自然薯さらに果樹・花卉などの栽培が行なわれ， 集約的な農業が行なわれる，木）都市近郊における 住宅・工業化と近郊農業. 自然を活かした別荘地な
ど高級住宅地や温室・ビニールハウスなど高度な農 地が出現する.

以上は砂丘地の開発類型の概観であるが，戦後の 地域開発は，低度な土地利用である砂丘地にも注意 が向けられ，種々の計画が立案され開発がすすめら れてきた。「地域開発」の意義については，1. 国や 地方自治体の公共（先行）投資によること，2. 総 合的であり，計画的であること.の 2 点から限定し， その顕著な実例として鹿島地域を挙げることとした。 換言せぱ，へ）総合性・計画性の開発という段階と して農工両全の土地利用という点から考えてみたい.

\section{II 鹿島地域の開発の目的・経過・計画}

鹿島地域開発の目的は次の諸点にある，イ）京浜 地域は東海道メガロポリスの中核として, その発展 は著しく, 工業の過集中を招き, 過大都市問題や公 害の発生など種々の問題をひきおこすに至った。 そ の解決策として首都圏整備法が公布され, 周辺地域 に工業衛星都市を積極的に造成し，工業の分散をは かるとともに，開発の拠点とする．ロ）首都圏の周 辺地域では産業構造の高度化, 経済水準の向上を図 り，核心地域との地域差を解消しょうとする，八） 企業側では国際競争力をもつ大規模工場の建設. 二）この国・東京，地元企業の 3 者の要請にこたえ， 鹿島地域という開発可能性をもつ低位生産地の開発 （自然改造）をはかる小）な打開発にあたっては， 工業開発のみでなく，農工両全という形をとって，

* 東京教育大学 
農業開発をも重点とし，新しい地域の 開発を意図する ${ }^{11}$.

昭和 35 年, 県によって鹿島地域の 総合開発の構想が始められた. 続いて 37年鹿島港は地方港湾に指定され外港 の試験堤が着工，同時に用地の買収が 開始された(標準坪あたり 630 円)，翌 38年重要港湾に指定となり，港の造成 は国で行なわれることとなった。なお 工業整備特別地域に指定. 41 年進出企 業(第 1 図参照) 発表，また $39 \sim 43$ 年 にわたって掘込港着工のため, 居切 浜・深芝浜の住民の農業団地への移転 が実施され，42年 3 月には国鉄鹿島線， 5 月には製鉄所の着工となった。この ように高度成長期に対応し，砂丘地域 の総合開発が進行していったのである. 計画の概要は次のようである. 工業 地域 4,000 ha，準工業地域 1,670 ha, 住宅地域 4,000 ha, 商業地域 330 ha 計 10,000 ha（3,000 坪）が指定. そのう

ち工業用地 3,300 ha には 25 企業が進出, 年生産額 1 兆 1719 億円, 従業員 30,468 人, 用水 196 万 $\mathrm{m}^{3}$ /日， 操業は昭和 43 年 12 月から 46 年 10 月まで，完成時 の工業規模は, 昭和 42 年の川崎・名古屋・横浜級 の生産額にほぼ等しい，そして当地域の総人口は 5.7 万人（35 年）から 30 万人（将来） へ，就業者 は第 1 次産業で 2.0 万 $\rightarrow 1.2$ 万, 第 2 次 0.3 万 $\rightarrow 5.8$ 万, 第 3 次 0.5 万 $\rightarrow 5.2$ 万へと変化を想定し, 中心 都市としては 15 万の中都市の構想を考えている.

\section{III 工 業 開 発}

現在は製鉄所のみが建設中である. 敷地 200 万坪, 1,000 万トン規模（高炉 5 ）の国際級であるが，立 地条件として，イ）京浜に近接 (約 $80 \mathrm{~km}$ )， 口）掘 込港の存在，八）地盤良好，二）用水の豊富が挙げ られている.この地域は砂礫層ののる台地で, 地耐 力が大きく, 建築のための杭打ちの必要なく，また 平坦であって整地の必要もない22. また砂質である ため, 水面上はダンプカーで運び去り，水面下はサ ンドポンプで掘り下げて港をつくるという. 工事の
容易性が有利に働いている．掘込港の水深を -7.5 $\mathrm{m}$ から $-16 \mathrm{~m}$ という深さにできるのも砂丘地だか らといえる.なお広くて安い用地の獲得も砂丘地の 特色をいかしたからである.

生活の場として地域住民の配慮は公害防止の対策 に見られる. 進出企業の煙突の高さ平均 $45.8 \mathrm{~m}$ を $90 \mathrm{~m}$ (東電火力は $180 \mathrm{~m}$ ) にし， 30 本を 17 本へと集 合させた. さらに硫黄分の少ない石油使用, 幅 1 キ 口の緩衝地帯の設置（この際は防風林が有効となろ う), 10 年以内に防止施設を作らず違反した場合に 契約解除などの方針をたてている.

\section{IV 農 業 開 発}

農業については，いわゆる「鹿島方式」がうち出 された．それは工業用地用に農地を提供しても, 農 業の継続を希望した人に対しては, もとの農地の 60 \%を替地造成によって還元するという方式である. そしてょり少ない農地の土地利用については, 補助 によって近代化・高度化をはかり，従来よりも生産 性を高めて, 生活水準の向上をしょうというのであ

1）高橋丈夫 (1968)：鹿島の開発，日本地誌 5 (青野寿郎・尾留川正平編), $381 \sim 387$.

2）多田文男 (1948)：鹿島半島の侵蝕砂丘. 地理評，21，9，10，10., 19 p. 
る.

砂丘地域には未利用の国有地が広く 存在していた。とくに部分的に存在す る砂丘が自然のまま放置されていた。 それらを機械力で整地し農業替地の造 成をはかった．29 地区で合計 $1,592.4$ ha で 925 戸分に相当する (第 1 図). そして，この替地には簡易水道・遊園 地・下水兼用の排水溝, 防風林・防風 栅が設けられた．またビニール水田や ビニール温床, 養豚場など近代化に対 しては半額の補助金を出すこととした. ビニール水田とは，水の浸透を防ぎ， 高温を保たせるため砂質地の地下約 1 $\mathrm{m} \sim 1.5 \mathrm{~m}$ にビニールを張ったもので, ダンプカーを使えば反当り 12 万円で 2 日間で作成 される. 昭和 42 年には計 258 ha がビニール水田と なり，反あたり $480 \mathrm{~kg} \sim 600 \mathrm{~kg}$ の多収穫が報告され た.ビニール温床はピーマンと西瓜・トマトの輪作 が一般的で，ピーマンは 4 月 12月に収穫，反当り 30万円，暖房を設ければ 50 万円の収入が得られる. 西瓜は 2 月中旬 8 月, その後卜マトで, 反当り 50 万円となる ${ }^{3)}$. なお畑地かんがい設備は勿論完備し ており，県では一戸あたり農業所得を 30 万円から 53 万円（昭和 45）に高めようとしているが，既に 実現されているようである.

北若松農業団地は 50 戸の規模で昭和 43 年度完了 の予定. 武蔵野の新田集落に類似した形態で，道路 に沿って宅地が並び，それに直角に短冊状の地割り がなされ，一部がビニール温床，ビニ一ル水田とな っている（43年 9 月には，まだ農地が完備せず，荒 地や落花生畑が各農地面積の半ばあまりを占めてい た).

先行投資や補助金の交付があれば，いままで低位 生産地とみなされてきた砂丘地域が，近代的な高位 生産地に変容する可能性を, この鹿島地域の開発が 示している.

\section{V 開発に抬ける問題点}

農業替地は工業用地の間（北若松の例）や住宅・
準工業地域の中につくられている. 工業活動の開始 前である現在時では農業に専念できようが，全操業 時には，果して農業が持続できるかが問題となる. すなわち, 公害発生, 工業労働力の需要増大，また 商業や住宅地さらに中小工業地に適することから土 地の高騰, これらによって恐らく農業の維持は困難 になることが予測される. 大野原団地では移転完了 した農家 81 戸のうち，主要道路に面した 24 戸は非 農業に転じたり，兼業経営をとったりしている，家 具・金物・ガソリンスタンド・食堂・飲み屋・食料 品・電気製品・クリーニング・ほか 1 週間の契約単 位の間貸しなど多彩な近隣中心の商店街を早くも形 成するに至っている．地震むいまでは坪あたり 2 万 ～2.5 万円，主要道路沿いでは $4 \sim 5$ 万円もすると いう. 大野原団地は工業地域のほぼ中心に位置し， 地域の中心に発達すべき要素を備えている. 北若松 もまた農業地としてょいかは問題である. 県では, これらの団地が住宅・都市化してもよいように排水 路は下水兼用となっているなど考慮しているという が，総合的・計画的な地域開発としては問題がある.

この鹿島地域の商圈は，中心の都市を欠いていて 不安定な状態におかれていることを筆者の一人が発 表している4)．地区中心としては銚子・佐原がある が，それらは隣県の千葉県にあり，鹿島地域では鹿 島の小さな町があるにすぎない、），かつて工業地域

3）大野原農業団地の一例をみると, 農地 1.78 ha（うち宅地 0.03 ha）で, ビニル水田 1.05 ha, プリンスメ

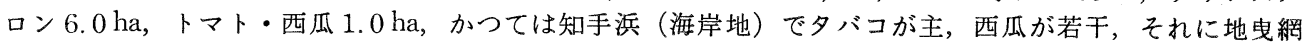
やハマグリ採取などを行っていた。こ扎に比べれば，今の方が収入多く安定している。 
の開発は，既成の都市地域かその近接地に形成され た. その点で, 鹿島地域は例外的であり, 生活中心 の場の育成ということが, 総合開発の大きな課題の 1 つにならなければならない. 消費物資・娛楽・衛 生・文化・教育など都市機能をもつ中心都市の育成 と，それに伴う都市計画の点において，考慮すべき 問題が存在する.

地域開発は，国や地方自治体，企業，地域住民の 各立場をそれぞれ活かした総合性・計画性が尊重さ れねばならない。

\section{VI 砂丘地の地域開発について}

総合性の開発といっても，そこには中心となるも ののあることはいうまでもない，その中心をどこに おくかは，全国的な国土利用計画の中から定めるべ きである，開発を強調せば，工業や都市化があげら れようし, 生活の立場に立てば, 砂丘地は農用地や レクリエーション地という緑地の造成と保存があげ られよう。そのいずれに中心を抢くかは，砂丘地が， 太平洋ベルトか外縁地帯か，また大都市圈の中心部 か外縁部かという位置を考慮に入れるべきである。
電島地域は太平洋ベルトの東縁という位置の故に工 業開発を中心とした地域開発になったのである. 次に砂丘地の特色を充分に活用すべきである.

亿）未利用地や低位生産地（とくに旧軍用地）は 広くて安い土地を提供し，また少ない補償や代替地 の提供がある. 口）砂丘地域は掘り込みや整地が容 易であり, また硬い地盤は建築物の構築に好適であ る.八）高燥・高温性は農業にとって高位生産地一 の転化が可能である。 二）自然美と防風林はレクリ エーション地・住宅地として好条件であり, また工 場公園の設置や公害防止にも利用価值が高い。これ らの特色は資本や技術の有効的な投下によって充分 に活用さるべきである.

さらには，地域開発にあたっては，工業的・農業 的・都市的の計画の一貫性が必要である.すなわち 広義の都市計画がマスタープランとして設計さるべ きである，そして農業における正しい見通しをたて る必要があるように，他産業との競合をつねに考え ねばならない、また, 公害防止をはかり, 自然美を 破壊しないように，砂丘地域のもつ自然的な，また 生態学的な論理に基づくべきであろう.

\section{SOME PROBLEMS OF REGIONAL DEVELOPMENT AND SAND DUNE AN EXAMPLE OF THE KASHIMA AREA}

\section{Shozo YAMAMOTO* Kiyoshi SAWADA*}

The Kashima area in the southeastern Ibaragi prefecture is the typical one with some sand dunes in Japan. Large number of projective efforts for developing this area has been done since 1960, with the objectives as the following: 1) constructing a inland port as focus of the industrial zone highly spaced along the Pacific coast, having many large steel plants and oil-chemistry industrial combinate, which lead to make this zone a growth pole stimulating to industialize the northern Kanto district, and 2) modernizing and rationalizing the initially lower agriculture in its productivity, which level up the living of inhabitants in this area.

This area is projected to have 330 ha in the space of the industrial zone and 1,200 billion yen in the value of the industrial production: the same scale as in the Kawasaki or the Yo-

\footnotetext{
4）沢田 清（1965）：地方都市の商圈の変容——関東地方における地域の例一一東京教育大学地理学研究 報告 IX, 129 134.

5）昭和 39 年の商業従事者数では, 銚子 7,298, 佐原 4,318 に対し, 鹿島町は 759 で, 階層的にみてより下 位にあることが推測できる。

Geographical Review of Japan 42-3 $1969 . \quad$ * Tokyo Kyoiku Univ.
} 
kohama industrial area. Out of twenty-five enterprises be established, an iron foundry (having 10 million ton in the capacity of its annually producing steel) has already been constructed in using the inland port. In agricultural phase, the farming lands which many farmers were forced to move into by the construction of the inland port or the industrial zone have intensively been utilized through the introduction of new technologies such as puddy fields covered by vinyl sheets, vinyl houses, and irrigating to dry fields.

However, the operation of such projects results to make actual the anxiety that the operation or maintenance of farming in this area would be in difficulties due to the growth of public nuisance, the lack of labor forces. and the rapid increase of land values. Yet, the population of this area is expected to increasingly change from 57,000 to 300,000 , but in this point also the problem how to establish central place of the inhabitants' living unit area is provided. Addition, to this, the efforts for urban planning of this area are not sufficiently done, beeing buried in the projections of industrial and agricultural developments.

Initially, in Japan characterized in puddy fields as a whole, some sand dunes have not productively been used due to their lack of water, their paticular heights and dryness, and their partial distribution. An example of the projective efforts in the Kashima area is a very clear evident that these efforts make possible highly using even sand dunes in industry and agriculture. Thus, although the rich fruits in their industrial facets are growing, the great problems in their facets of the inhabitants' life, the lack of urban planning, are provided.

コメント

\section{「後進地域の地域開発」世話人の立場から}

\section{河野 通 博*}

このコメントは本来ならば「後進地域の地域開 発」についての問題提起者の討諭の上に立って，そ れを総括した形で報告すべきものであったが，現実 にはその時間的余裕が与えられていなかったので， 私個人の見解を述べることになった.

1. 現在の「後進地域開発」事業は企業誘致によ る「工業化」を主軸として展開されており，その立 場からすれば砂丘は建設用骨材を提供するものとし て以上には多くの地域では評価されないと言う，見 放された状態にある．だが鹿島工業整储特別地域の ように，産業基盤整備の対象となりうる場合も存在 するわけで，全く工業化と無縁なわけではない，し かしそれを決定するのは全く別の政治的・経済的要 因であり，その場合にも地域住民にとって農業開発 か工業用地造成かはそれほど簡単にきめられること ではない。むしろ農業的土地利用と工業的土地利用
の競合に対して，地域住民は十分将来の展望を考虑 しつつ, 慎重な判断の下に行動すべきである.

2. 現在のところ, 大部分の後進地域では砂丘は 専ら農業的開発の対象となりうるだけで, そこで行 なわれているのは防砂林帯の造成と，その背後にお ける花・そ菜などの労働集約的な園芸農業である. しかし現在および将来の需給構造を見通してみると これらの園芸農業の主産地たりうるためには，かな り広域的に（少くとも数力町村, 可能なれば数郡に わたる）砂丘改造を実施して，統一規格による大量 出荷に踏み切らなくてはならないだろう.

3. その場合各経営農家は水稲作と組合わせた多 角経営か, 専業的大規模経営かを二者択一的に決定 しなくてはならないだろう. だがいずれにしても労 働力流出の激しい後進地域では労働力の調達が一つ のネックになるだろう。もし家族労働のみに依拠す

\footnotetext{
岡山大学
} 
るのなら，零細な多角経営の集積になるだろうし， 生産性の向上はあまり望めないだろろ.

4. もし近代的大規模農業にふみ切るとすれば省 力的砂丘利用を実現するためには，畑地灌溉施設， 輸送機械などの整備をはじめ, 農業近代化のための かなりの投資が必要であるが，その資金調達はいか
にして可能となるだろうか。そしてそれだけの投資 に見合う農業収益を保証するだけの農産物価格はい かにして維持できるだろうか.いわば農業構造改善 事業全般に共通する問題点が，砂丘開発の場合，一 層大きな重圧となるのではあるまいか.

\section{5）討 論}

\section{海 岸 砂 丘—その自然と開発}

\section{吉川虎雄* ・ 尾留川正平**}

討論 午前中になされた「日本の海岸地形と砂 丘」および「砂丘の形成営力」に関する問題提起な らびにコメントから，次の 3 点について討論した.

\section{1. 砂丘の形成期}

日本各地の新旧の砂丘が，第四紀におけるかなり 限られたいくつかの時期に形成されたと考えられる ことが指摘され，砂丘の形成と海面変化や気候条件 との関連について論ぜられた.しかし，問題提起者 の間にも，砂丘の形成期について意見の一致しない 点があり，地盤運動の地域的特性を考えれば，砂丘 形成期が全国的にそろうことには疑問があるとの意 見も出された.これに関連して，砂丘の区分・対比 に用いられる古土壌やクロスナの意義がかならずし む明確になっていないこと，砂丘との層位関係につ いてのべられた段丘の概念があいまいであること， また古土塞の形成や考古学的遺物の変遷などの速さ にくらべて，砂丘の形成はきわめて速いと考えられ るので，これらの criteria を用いて砂丘の形成期を 対比することは危険であることなどが指摘された.

2. 砂丘の立地条件

砂丘の形成は，地域的な条件に支配されるところ が大きいし，先史地理の立場から砂丘を研究する場 合には，その後背地域の条件を考えることが重要で ある.このような見地から，砂丘を海岸低地の発達 との関連において正しくとらえることが必要である. この点については，問題提起において多少ふれられ たが，その分析は全体として不十分であった，また， 砂丘の基盤やその地形などは，砂丘の開発に関連す
る問題をふくんでいるが，このような観点から論議 することはできなかった。

3. 砂丘の形成営力

荒巻の問題提起において，年間飛砂量は予想外に 大きく，砂丘の形成はかなり速いであろうことが指 摘された. しかし，一方では，中山の指摘したよう に，飛砂の多い冬季には，海浜は侵蝕される傾向に あるから，砂の供給地である海浜の変遷を考えない と, 砂丘の形成される速さを飛砂量だけから直ちに 結論することはできない，この問題は，砂丘の形成 期を考えるのにも，また砂丘を開発利用するにあた っても, 重要であることがのべられた.

全体として，提起された問題の幅が広いにもかか わらず，討論時間がきわめて短かく，討論の内容も 十分かみ合うまでに至らなかった。また，午後に論 議された砂丘の開発につながる問題を取上げること ができなかったことは，はなはだ残念であった。

(吉川虎雄)

午後に発表された「砂丘利用の技術的問題点と経 済的問題点（農業生産を中心に）」と「地域 開発の 問題と砂丘」の問題提起およびコメントから，1. 砂丘の農業開発に打ける土地利用の高度化と農業経 営の安定性, 2. 農業的土地利用と住宅・工業・観 光地など都市的土地利用との競合および地域開発に おける役割意義にしぼって討論した。

1.については地力は低いが，灌溉技術や土地改 良などの技術的進歩が進んで, 成功例も多くみられ るようになった. しかし農民の土地所有規模の不足，

\footnotetext{
* 東京大学

** 東京教育大学
} 
資力の欠亡などによって不成功のものも多く，技術 の進歩とこれを生かし得ない農民集落の存在が重要 であるのに，成功例における技術進歩に伴う作物選 択が討論の前面に出てきだ. 技術面では開発に伴う 蒸発散量の変化に伴う地下水の変化に問題があり, 水収支研究の重要性は指摘されても, 灌溉法の導入 普及度の地域差から開発成功の条件が論じられなく て, 農学側の問題提起と地理側の問題提起討論が十 分にかみあわなかった
2.については鹿島・鳥取砂丘の例示があったが， 時間がなく, 農業的土地用, 都市的土地利用がばら ばらになりがちであり，十分な討論をすることがで きなかった. 砂丘の土地利用から砂そのものを原料 とする利用が進み, 砂丘環境の改変が提起されたが, 時間がなく, 砂丘をとり除いても砂丘形成の営力が 残る限り，そこの土地利用には研究すべき問題の多 いことを述べて会を閉した。（尾留川正平） 